\title{
Chimeric Platinum-Polyamines and DNA Binding. Kinetics of DNA Interstrand Crosslink Formation by Dinuclear Platinum Complexes with \\ Polyamine Linkers
}

\author{
Rasha A. Ruhayel, ${ }^{\dagger, \S}$ Janina S. Langner, ${ }^{\dagger, \S}$ Matilda-Jane Oke, ${ }^{\dagger}$ and Susan J. Berners-Price ${ }^{*, \dagger, \S}$ \\ ${ }^{\dagger}$ School of Biomedical, Biomolecular \& Chemical Sciences, The University of Western Australia, 35 Stirling \\ Highway, Crawley WA 6009 Australia \\ ${ }^{\S}$ Institute for Glycomics, Gold Coast Campus, Griffith University, Queensland, 4222, Australia
}

Ibrahim Zgani and Nicholas P. Farrell*

Department of Chemistry, Virginia Commonwealth University, Richmond, Virginia, 23284-2006 USA

\footnotetext{
$\S$ Present address: Institut für molekulare Biowissenschaften, Goethe Universität, Max-von-Laue Str. 9, 60438 Frankfurt am Main, Germany
} 
ABSTRACT: The first observation of a polyamine-DNA interaction using $2 \mathrm{D}\left[{ }^{1} \mathrm{H},{ }^{15} \mathrm{~N}\right] \mathrm{HSQC}$ NMR spectroscopy allows study of the role of the linker in polynuclear platinum-DNA interactions and a novel "anchoring" of the polyamine by Pt-DNA bond formation allows examination of the details of conformational $\mathrm{B} \rightarrow \mathrm{Z}$ transitions induced by the polyamine. The kinetics and mechanism of the stepwise formation of $5^{\prime}-5^{\prime} 1,4-\mathrm{GG}$ interstrand cross-links (IXLs) by fully ${ }^{15} \mathrm{~N}$-labeled $\left[\left\{\text { trans-PtCl}\left({ }^{15} \mathrm{NH}_{3}\right)_{2}\right\}_{2}\left\{\mu-\left({ }^{15} \mathrm{NH}_{2}\left(\mathrm{CH}_{2}\right)_{6}{ }^{15} \mathrm{NH}_{2}\left(\mathrm{CH}_{2}\right)_{6}{ }^{15} \mathrm{NH}_{2}\right)\right\}\right]^{3+}(1,1 / t, t-6,6, \mathbf{1})$ and $\left[\left\{\text { trans- } \mathrm{PtCl}\left({ }^{15} \mathrm{NH}_{3}\right)_{2}\right\}_{2}\left\{\mu-\left({ }^{15} \mathrm{NH}_{2}\left(\mathrm{CH}_{2}\right){ }_{6}{ }^{15} \mathrm{NH}_{2}\left(\mathrm{CH}_{2}\right)_{2}{ }^{15} \mathrm{NH}_{2}\left(\mathrm{CH}_{2}\right){ }_{6}^{15} \mathrm{NH}_{2}\right)\right\}\right]^{4+}\left(1,1 / t, t-6,2,6, \mathbf{1}^{\prime}\right)$ with the self complementary oligonucleotide 5 '-\{d(ATATGTACATAT) 2$\}($ duplex I) are compared to the analogous reaction with 1,0,1/t,t,t (BBR3464) under identical conditions (pH 5.4, $298 \mathrm{~K}$ ). Initial electrostatic interactions with the DNA are delocalized and followed by aquation to form the monoaqua monochloro species. The rate constant for monofunctional adduct formation, $k_{\mathrm{MF}}$, for $1\left(0.87 \mathrm{M}^{-1} \mathrm{~s}^{-1}\right)$ is 3.5 fold higher than for $1,0,1 / t, t, t\left(0.25 \mathrm{M}^{-1} \mathrm{~s}^{-1}\right)$ (the value could not be calculated for $\mathbf{1}^{\prime}$ due to peak overlap). The evidence suggests that several conformers of the bifunctional adduct form, whereas for $1,0,1 / t, t, t$ only two discrete conformers were observed. The combined effect of the conformers observed for $\mathbf{1}$ and $\mathbf{1}^{\prime}$ may play a crucial role in the increased potency of these novel complexes compared to $1,0,1 / t, t, t$. Treated as a single final product, the rate of formation of the $5^{\prime}-5^{\prime} 1,4-\mathrm{GG} \mathrm{IXL}, k_{\mathrm{CH}}$, for $\mathbf{1}\left(k_{\mathrm{CH}}=4.37 \times 10^{-5} \mathrm{~s}^{-1}\right)$ is similar to that of $1,0,1 / t, t, t$, whereas the value for $\mathbf{1}^{\prime}$ is marginally higher $\left(k_{\mathrm{CH}}=5.4 \times 10^{-5} \mathrm{~s}^{-1}\right)$. 


\section{INTRODUCTION}

Targeting DNA has contributed significantly to the development of the current anticancer drug armamentarium and DNA remains a clinically important target. ${ }^{1,2}$ DNA-binding drugs interact by the three "classical" binding modes of intercalation, groove recognition and covalent binding. Modulation of the inherent lack of tumor specificity of drug action, often using modern advances in molecular biology, has led to many imaginative approaches such as enhancing sequence specificity, delivery of site-specific drugs, and metabolic and/or photo-activation..$^{1-3}$ Concomitantly, there has been continued discovery of new molecular mechanisms by which small molecules recognize or interact with DNA. ${ }^{2}$ Especially, altered DNA conformations through new binding modes are also inspirational for new drug design. The targeting of intermediate DNA structures other than the canonical B-DNA may produce profiles of biological activity hitherto unknown as well as having broad applications in materials science, biology and medicine.,.$^{2,5}$

The acceptance of DNA as cellular target for the anticancer drug cisplatin and its structural analogs has led to detailed understanding of their modes of DNA binding, the consequent DNA structural perturbations and protein recognition, as well as effects on cellular signaling pathways. ${ }^{6,7}$ Structurally novel drugs, discrete from cisplatin and its analogs in both chemical structure and the nature of the Pt-DNA adduct, may expand the biological profile of platinum anticancer agents by circumventing and/or complementing cisplatin-specific biological processes such as DNA repair or indeed cellular accumulation pathways. Proof of principle of the utility of this approach is afforded by the advance of BBR3464, the trinuclear, bifunctional DNA binding agent [\{trans$\left.\operatorname{PtCl}\left(\mathrm{NH}_{3}\right)_{2}\right\}_{2}\left(\mu\right.$-trans-Pt( $\left.\left.\left(\mathrm{NH}_{3}\right)_{2}\left\{\mathrm{NH}_{2}\left(\mathrm{CH}_{2}\right)_{6} \mathrm{NH}_{2}\right\}_{2}\right)\right]^{4+}(1,0,1 / t, t, t$ or BBR3464) to Phase I and II clinical trials, the only non-cisplatin analog to be introduced to humans. ${ }^{8}$ 
BBR3464 belongs to the general class of polynuclear platinum complexes (PPCs), where two or three platinum coordination units are linked through flexible diamine chains. These PPCs comprise a structurally discrete class of platinum-based anticancer agents, ${ }^{8}$ and the elucidated modes of DNA binding are also very distinct. ${ }^{9}$ BBR3464 forms long-range $\{\mathrm{Pt}, \mathrm{Pt}\}$ interstrand crosslinks on guanine residues in duplex DNA. ${ }^{10,11}$ The formation of "directional" isomers, where crosslinks are formed in both the $5^{\prime} \rightarrow 5^{\prime}$ and the unusual antiparallel $3^{\prime} \rightarrow 3^{\prime}$ direction, is a unique feature of the DNA binding of polynuclear compounds. ${ }^{12,13}$ A second property of the DNA adduct structures is that the conformational changes are delocalized, with the syn nucloside conformations induced even in non-platinated purines. ${ }^{9,14}$ The combined effects of the structural distortions of the 1,4-interstrand crosslink (1,4-IXL) indicate a delocalized, conformationally flexible "Z-like" lesion, with structural changes transmitted beyond the binding site. This contrasts with the major 1,2-intrastrand adduct of cisplatin which, although bending the helix significantly, maintains the B-form in solution. ${ }^{15,16}$ Gel retardation assays showed only very weak recognition of 1,4-IXLs by high mobility group HMG1 proteins, ${ }^{12}$ which recognize the 1,2 -intrastrand adduct and whose action is implicated in the cytotoxicity of cisplatin. ${ }^{17,18}$ Differential protein recognition represents a molecular mechanism for differentiation of further downstream effects of the mononuclear and polynuclear adducts. The comparison between mononuclear and polynuclear platinum presents a good example of the general concepts discussed above.

The charged central linker has been implicated in electrostatic pre-associative interactions in the minor groove with duplex DNA (specifically to adenine $\mathrm{H}_{2}$ protons) as well as in the final bifunctional adducts. ${ }^{11,14,19,20}$ Incorporation of a linear polyamine, such as spermidine or spermine, into the basic polynuclear framework by replacement of the central tetraa $(\mathrm{m})$ mine unit of PPCs produces a series of dinuclear compounds which replicate the biological activity of the trinuclear 
drug. ${ }^{21-23}$ Systematic structure-activity relationships have identified $\mathbf{1}^{\prime}$ and its derivatives as a potential 2nd-generation candidate with exceptional cytotoxicity and antitumor activity. ${ }^{8}$ The structure $\left[\left\{\text { trans-PtCl}\left({ }^{15} \mathrm{NH}_{3}\right)_{2}\right\}_{2}\left\{\mu-\left({ }^{15} \mathrm{NH}_{2}\left(\mathrm{CH}_{2}\right)_{6}{ }^{15} \mathrm{NH}_{2}\left(\mathrm{CH}_{2}\right)_{2}{ }^{15} \mathrm{NH}_{2}-\left(\mathrm{CH}_{2}\right)_{6}{ }^{15} \mathrm{NH}_{2}\right)\right\}\right]^{4+} \quad(1,1 / t, t-6,2,6$ or $\mathbf{1}^{\prime}$, Chart 1) was designed to have the same length and overall charge as $1,0,1 / t, t, t$ but with the presence of the central ethylendiamine unit mimicking the H-bonding and electrostatic properties of the central Pt-tetraam(m)ine unit in $1,0,1 / t, t, t . \mathbf{1}^{\prime}$ is one of the most potent platinum agents reported with nanomolar cytotoxicity and an interesting profile of activity against gliomas and colon cancer cells ${ }^{24-26}$ It displays a similar global reactivity and DNA-binding profile to that of $1,0,1 / t, t, t^{26-28}$

Polyamines have been extensively studied for their ability to modify DNA conformation, especially in the context of the $\mathrm{B} \rightarrow \mathrm{Z}$ transition. ${ }^{29,30}$ It is therefore of interest to examine how the properties of two DNA-reactive agents may be combined to contribute to a discrete new binding mode producing a discrete set of biological properties in its own right. The effect of the dinuclear (central polyamine) versus trinuclear (central platinum tetraamine) linker on global DNA binding has been studied, ${ }^{21,22,28}$ but the intimate details on sequence-specific DNA are lacking. ${ }^{15} \mathrm{~N}$-labeling of the polyamine ligands allows for use of $2 \mathrm{D}\left[{ }^{1} \mathrm{H},{ }^{15} \mathrm{~N}\right]$ HSQC NMR spectroscopy, now extensively used for study of DNA platination reactions. ${ }^{31}$ This paper describes a systematic study of the stepwise formation of $5^{\prime}-5^{\prime}$ 1,4-GG interstrand crosslinks in the DNA duplex 5'-\{d(TATAGTACTATA $\left.)_{2}\right\} \quad$ (duplex I) by $\mathbf{1}^{\prime}$ and its closest spermidine-based analog, $\mathbf{1}$ $\left[\left\{\text { trans }-\mathrm{PtCl}\left({ }^{15} \mathrm{NH}_{3}\right)_{2}\right\}_{2}\left\{\mu-\left({ }^{15} \mathrm{NH}_{2}\left(\mathrm{CH}_{2}\right)_{6}{ }^{15} \mathrm{NH}_{2}\left(\mathrm{CH}_{2}\right)_{6}{ }^{15} \mathrm{NH}_{2}\right)\right\}\right]^{3+}(\mathrm{BBR} 3007,1,1 / t, t-6,6$ or 1, Chart 1) The results are compared to those previously found for $1,0,1 / t, t, t^{11}$ and the dinuclear counterpart $1,1 / t, t .{ }^{10}$ We further show the potential of $2 \mathrm{D}\left[{ }^{1} \mathrm{H},{ }^{15} \mathrm{~N}\right]$ HSQC NMR in elucidating intimate details of the polyamine-DNA interaction. For the interaction of spermine with the self-complementary 
$\mathrm{d}(\mathrm{CGCGAATTCGCG})_{2}$ the mobility of the spermine molecule was effectively independent of that of the duplex. ${ }^{32}$ Anchoring the polyamine through platination of the terminal amines allows for (i) a direct comparison of how the central linkers in polynuclear platinum complexes affect DNA reactions and (ii) analysis of how the polyamine moiety itself associates (and pre-associates) with the oligonucleotide in solution.

\section{(Insert Chart 1 here)}

\section{EXPERIMENTAL SECTION}

Chemicals. The acetate salt of the oligonucleotide $\left.5^{\prime}-\{\text { d(ATATGTACATAT })_{2}\right\}($ duplex I) was purchased from GeneWorks (Australia). The nitrate salts of the fully ${ }^{15} \mathrm{~N}$ labeled $\left[\left\{\text { trans }-\mathrm{PtCl}\left({ }^{15} \mathrm{NH}_{3}\right)_{2}\right\}_{2}\left\{\mu-\left({ }^{15} \mathrm{NH}_{2}\left(\mathrm{CH}_{2}\right)_{6}{ }^{15} \mathrm{NH}_{2}\left(\mathrm{CH}_{2}\right)_{6}{ }^{15} \mathrm{NH}_{2}\right)\right\}\right]^{3+} \quad \quad\left({ }^{15} \mathrm{~N}-\mathbf{1}\right) \quad$ and $\left.\left[\left\{\text { trans-PtCl}\left({ }^{15} \mathrm{NH}_{3}\right)_{2}\right\}_{2}\left\{\mu-\left({ }^{15} \mathrm{NH}_{2}\left(\mathrm{CH}_{2}\right)_{6}{ }^{15} \mathrm{NH}_{2}\left(\mathrm{CH}_{2}\right)_{2}{ }^{15} \mathrm{NH}_{2}\left(\mathrm{CH}_{2}\right)_{6}{ }^{15} \mathrm{NH}_{2}\right)\right\}\right]\right]^{4+}\left({ }^{15} \mathrm{~N}-\mathbf{1}^{\prime}\right)$ were prepared using methods delineated elsewhere..$^{33}$

NMR Studies. The NMR spectra were recorded on Bruker AVANCE $600 \mathrm{MHz}$ spectrometer $\left({ }^{1} \mathrm{H}, 599.92 \mathrm{MHz} ;{ }^{15} \mathrm{~N}, 60.79 \mathrm{MHz} ;{ }^{31} \mathrm{P}, 242.94 \mathrm{MHz}\right)$. The ${ }^{1} \mathrm{H}$ spectra were internally referenced to TSP (sodium-3-trimethylsilyl- $\mathrm{D}_{4}$-propionate) and the ${ }^{15} \mathrm{~N}$ chemical shifts externally referenced to ${ }^{15} \mathrm{NH}_{4} \mathrm{Cl}\left(1.0 \mathrm{M}\right.$ in $1.0 \mathrm{M} \mathrm{HCl}$ in $5 \% \mathrm{D}_{2} \mathrm{O}$ in $\left.\mathrm{H}_{2} \mathrm{O}\right)$. The ${ }^{1} \mathrm{H}$ spectra were acquired with water suppression using the WATERGATE pulse sequence. ${ }^{34}$ The $2 \mathrm{D}\left[{ }^{1} \mathrm{H},{ }^{15} \mathrm{~N}\right] \mathrm{HSQC}$ (heteronuclear single-quantum coherence) NMR spectra (decoupled by irradiation with the GARP-1 sequence during acquisition) optimized for ${ }^{1} J\left({ }^{15} \mathrm{~N}, \mathrm{H}\right)=72 \mathrm{~Hz}$ were recorded using the standard Bruker phase sensitive HSQC pulse sequence. ${ }^{35}{ }^{31} \mathrm{P}$ spectra were referenced externally to phosphoric acid and acquired with a zgig pulse sequence. ${ }^{35}$ Typically for $1 \mathrm{D}{ }^{1} \mathrm{H}$ spectra 32 transients were recorded with spectral width of $12 \mathrm{kHz}$ and a relaxation delay of $1.5 \mathrm{~s}$. For $2 \mathrm{D}\left[{ }^{1} \mathrm{H},{ }^{15} \mathrm{~N}\right] \mathrm{HSQC}$ NMR 
spectra 8 transients were collected for 128 increments of $t_{1}$ with an acquisition time $0.152 \mathrm{~s}$ and spectral widths of $2 \mathrm{kHz}$ in $f_{2}\left({ }^{1} \mathrm{H}\right)$ and $1.8 \mathrm{kHz}$ in $f_{2}\left({ }^{15} \mathrm{~N}\right)$. 2D spectra were completed in 14 min and were processed using Gaussian weighting functions in both dimensions. For ${ }^{31} \mathrm{P}$ NMR spectra, 128 transients were recorded with a spectra width of $4.8 \mathrm{kHz}$ and a relaxation delay of $0.25 \mathrm{~s}$ with an acquisition time of $3.38 \mathrm{sec} .64 \mathrm{~K}$ data points were used for processing.

pH Measurements. The $\mathrm{pH}$ of the solution was measured using a Shindengen ISFET (semiconductor) $\mathrm{pH}$ meter (pH Boy-KS723 (SU-26F)) and calibrated against buffers of $\mathrm{pH} 4.0$ and 6.9. To avoid leaching of chloride into the sample, aliquots removed from the solution were not returned to the sample. The $\mathrm{pH}$ meter was calibrated using $\mathrm{pH} 4.0$ and 6.9 buffer solutions. Adjustments in $\mathrm{pH}$ were made using 0.2, 0.04 and $0.01 \mathrm{M}$ solutions of $\mathrm{HClO}_{4}$ and $\mathrm{NaOH}$.

DNA Preparation. The acetate salt of duplex I was desalted by means of a NAP-25 column. All solutions used for the desalting process were filtered through $2.5 \mu \mathrm{m}$ filters. The sample was made up to $2.5 \mathrm{~mL}$ by using MilliQ $\mathrm{H}_{2} \mathrm{O}$. The NAP-25 column was first rinsed with MilliQ $\mathrm{H}_{2} \mathrm{O}$ $(25 \mathrm{~mL})$ then the sample was loaded onto the column and eluted with MilliQ $\mathrm{H}_{2} \mathrm{O}(3.5 \mathrm{~mL}(\times 4))$. The DNA sample was collected in the first $2.5 \mathrm{~mL}$ to elute out of the column and was then freeze dried. Two different samples of duplex $\mathbf{I}$ were prepared for the two experiments with $\mathbf{1}$ and $\mathbf{1}^{\prime}$ as follows: Duplex I was dissolved in MilliQ $\mathrm{H}_{2} \mathrm{O}\left(\mathbf{1}: 335 \mu \mathrm{L}, \mathbf{1}^{\prime}: 221.75 \mu \mathrm{L}\right)$, then $\mathrm{Na}_{3} \mathrm{PO}_{4}$ buffer (1: $\left.18 \mu \mathrm{L}, \mathbf{1}^{\prime}: 11.25 \mu \mathrm{L}, 400 \mathrm{mM}, \mathrm{pH} 5.4\right), \mathrm{D}_{2} \mathrm{O}\left(\mathbf{1}: 24 \mu \mathrm{L}, \mathbf{1}^{\prime}: 15 \mu \mathrm{L}\right)$ and $\mathrm{TSP}(2 \mu \mathrm{L}, 13.3 \mathrm{mM})$ were added to the NMR tube. To anneal the duplex, the sample was heated in a water bath to $90{ }^{\circ} \mathrm{C}$ and then allowed to cool to room temperature over a few hours. The concentration of duplex I was estimated by using UV spectrophotometry and ${ }^{31} \mathrm{P}$ NMR (relative to a known concentration of $\left.\mathrm{PO}_{4}{ }^{3}\right)$ 
Reaction of Duplex I with 1 and 1'. A freshly prepared solution of either ${ }^{15} \mathrm{~N}-1(0.46 \mathrm{mg}, 0.49$ $\mu \mathrm{mol})$ or ${ }^{15} \mathrm{~N}-\mathbf{1}^{\prime}(0.37 \mathrm{mg}, 0.35 \mu \mathrm{mol})$ was dissolved in MilliQ $\mathrm{H}_{2} \mathrm{O}\left(\mathbf{1}: 100 \mu \mathrm{L} ; \mathbf{1}^{\prime}: 50 \mu \mathrm{L}\right)$ such that the final concentration in the respective NMR sample $\left(\mathrm{V}_{\text {final }} \mathbf{1}: 480 \mu \mathrm{L}, \mathbf{1}^{\prime}: 300 \mu \mathrm{L}\right)$ was $\sim 1$ $\mathrm{mM}\left(\mathbf{1}: 1.02 \mathrm{mM}, \mathbf{1}^{\prime}: 1.17 \mathrm{mM}\right)$. To start the reaction the solution of ${ }^{15} \mathrm{~N}-\mathbf{1}$ or $-\mathbf{1}$ was added to the sample of the duplex (preparation as described above) so that the final concentration of duplex $\mathbf{1}$ was $\approx 1 \mathrm{mM}\left(1: 1.14 \mathrm{mM}, 1^{\prime}: 1.12 \mathrm{mM}\right)$ in $15 \mathrm{mM} \mathrm{Na}_{3} \mathrm{PO}_{4}$ in $5 \% \mathrm{D}_{2} \mathrm{O}$. The $\mathrm{pH}$ of the samples was adjusted to $\mathrm{pH} 5.4$ using $0.01,0.02$ and $0.05 \mathrm{M}$ solutions of $\mathrm{HClO}_{4}$ in $95 \% / 5 \% \mathrm{H}_{2} \mathrm{O} / \mathrm{D}_{2} \mathrm{O}$. Aliquots removed were not returned to the sample (as the electrode leaches $\mathrm{Cl}^{-}$). The reactions were followed by $1 \mathrm{D}{ }^{1} \mathrm{H}$ and $2 \mathrm{D}\left[{ }^{1} \mathrm{H},{ }^{15} \mathrm{~N}\right] \mathrm{HSQC}$ NMR at $298 \mathrm{~K}$ to completion. The final $\mathrm{pH}$ of the sample containing $\mathbf{1}$ was 5.7 and that containing $\mathbf{1}^{\prime}$ was 5.3.

Data Analysis: Kinetic analyses of the two reactions were undertaken by measuring peak volumes in the $\mathrm{Pt}^{15} \mathrm{NH}_{3}$ region of the $2 \mathrm{D}\left[{ }^{1} \mathrm{H},{ }^{15} \mathrm{~N}\right] \mathrm{HSQC}$ NMR spectra using the plug-in '2D NMR Analysis' developed for ImageJ. ${ }^{36}$ Peak volumes were then converted into concentrations relative to the initial concentration of the Pt complex, after correcting for peak overlap as described previously. ${ }^{11}$ Differential equations were used to fit the data and rate constants determined using a non-linear optimization process using SCIENTIST (Version 2.0, MicroMath Inc.). All errors reported are for one standard deviation and are fit to either pseudo first- or second-order rate equations.

\section{RESULTS}

The platination of the self-complementary duplex $5^{\prime}-\left\{\right.$ d(TATAGTACTATA) $\left.{ }_{2}\right\}$ (duplex I) with

${ }^{15} \mathrm{~N}-\mathbf{1}$ and ${ }^{15} \mathrm{~N}-\mathbf{1}^{\prime}$ was followed using 2D $\left[{ }^{1} \mathrm{H},{ }^{15} \mathrm{~N}\right] \mathrm{HSQC}$ and ${ }^{1} \mathrm{H}$ NMR spectroscopy. This methodology follows on from that reported previously for the reaction of both $1,1 / t, t^{10}$ and 
$1,0,1 / t, t, t^{11}$ with $\mathbf{I}$ and the conditions chosen (298 K, pH 5.4) allow for the most direct comparison with the results of these studies. Complexes $\mathbf{1}$ and $\mathbf{1}^{\prime}$ are the first examples of PPCs containing ${ }^{15} \mathrm{~N}$-labeled polyamine linkers to be studied using $2 \mathrm{D}\left[{ }^{1} \mathrm{H},{ }^{15} \mathrm{~N}\right]$ HSQC NMR spectroscopy. ${ }^{33}$ To our knowledge, no free polyamines have been examined by this technique. As a consequence, the behavior of the central (non-coordinated) $-{ }^{15} \mathrm{NH}_{2}-$ groups upon the addition to DNA was also explored to obtain information on the interactions of the central linker with DNA. As a corollary, "fixation" of the terminal amine end by covalent $\operatorname{Pt}\left(\mathrm{N}_{7} \mathrm{G}\right)$ binding may also elucidate aspects of the binding of the central $-\mathrm{NH}_{2}-$ groups.

The DNA binding of these bifunctional platinum drugs follows the stepwise sequence observed previously, ${ }^{10,11}$ with evidence for non-covalent association through electrostatic interaction and hydrogen-bonding, aquation followed by monofunctional covalent binding and finally fixation of the interstrand cross-link through bifunctional binding (Scheme 1). The chemical shifts of all intermediate and bifunctional product species observed during the reactions of ${ }^{15} \mathrm{~N}-\mathbf{1}$ and $\mathbf{- 1} \mathbf{1}^{\prime}$ are summarized in Tables 1 and 2. Representative $\left[{ }^{1} \mathrm{H},{ }^{15} \mathrm{~N}\right]$ HSQC NMR spectra for the two reactions are shown in Figure 1 and plots showing changes in selected regions of the ${ }^{1} \mathrm{H}$ NMR spectra are shown in Figure 2 and Figures S1 and S2 in the Supporting Information.

(Insert Scheme 1, Table 1 and Figures 1 and 2 here)

Pre-covalent Binding Step. The ${ }^{1} \mathrm{H}$ NMR resonances in the aromatic region of duplex I were assigned from $2 \mathrm{D}{ }^{1} \mathrm{H}$ NOESY data (Table S1) allowing for identification of specific changes that occurred immediately upon the addition of $\mathbf{1}$ and $\mathbf{1}^{\prime}$ to duplex $\mathbf{I}$. Pre-covalent electrostatic interactions between PPCs and DNA are commonly observed in the minor groove resulting in a chemical shift change of the adenine $\mathrm{H} 2$ aromatic protons by approximately $\delta 0.07-0.3 \mathrm{ppm} .{ }^{11}$ For 
both PPCs minor changes $(\Delta \delta<0.03)$ were observed for these protons. In the case of $\mathbf{1}$, it appears that pre-association occurs towards the $3^{\prime}$ end of $\mathbf{I}$, with the largest shifts seen for the $A_{7}$ and $A_{11}$ $\mathrm{H} 2$ protons (Figure 3a). These results further indicate that the pre-association changes are quite delocalized over a 5-base pair $\left(\mathrm{A}_{7}-\mathrm{A}_{11}\right)$ region. On the other hand 1' appears to pre-associate symmetrically along the DNA. The most notable changes occur for the $\mathrm{H} 2$ protons of $\mathrm{A}_{3}, \mathrm{~A}_{7}$ and $\mathrm{A}_{11}$, as well as the H6 proton of the $\mathrm{C}_{8}$ residue (Figure $3 \mathrm{~b}$ ). This difference may be a consequence of the longer length of $\mathbf{1}^{\prime}$ compared to $\mathbf{1}$ leading to a more delocalized interaction. The preassociation of $\mathbf{1}^{\prime}$ is also significantly more extended (delocalized) than observed for $1,0,1 / t, t, t$ as might be expected by the less severe steric constraints of the polyamine linker compared to the Pt(tetraamine) sphere. ${ }^{5}$

\section{(Insert Figure 3 here)}

Differences in the interactions of the two complexes with duplex $\mathbf{I}$ are evident also from the ${ }^{1} \mathrm{H}$ shifts of the polyamine linker (Figure S1). Upon the addition of $\mathbf{1}$ to duplex $\mathbf{I}$, no significant changes were observed in the ${ }^{1} \mathrm{H}$ chemical shifts for the 2 and $5 \mathrm{CH}_{2}$ groups (for numbering see Chart 1). On the other hand for $\mathbf{1}^{\prime}$, on addition to duplex $\mathbf{I}$ the broad multiplet for the $2 / 5 \mathrm{CH}_{2}$ groups $(\delta 1.70)$ splits into two resonances $(\delta 1.70$ and 1.75) (Figure S1b). This pattern is consistent with pre-association of the polyamine linker in the minor groove, and symmetrically along the length DNA sequence, as indicated by the changes in shift of the adenine $\mathrm{H} 2$ aromatic protons (Figure 3b). For $1,0,1 / t, t, t$ there was no splitting of the multiplet for the $2 / 5 \mathrm{CH}_{2}$ groups in the presence of duplex I, however non-equivalent $2 / 5 \mathrm{CH}_{2}$ groups were observed in the presence of the sequence $5^{\prime}-\left\{\mathrm{d}(\mathrm{TATGTATACATA})_{2}\right\} .^{11}$

The pre-association step was also monitored in the $2 \mathrm{D}\left[{ }^{1} \mathrm{H},{ }^{15} \mathrm{~N}\right] \mathrm{HSQC}$ NMR spectra by comparing the ${ }^{1} \mathrm{H}$ and ${ }^{15} \mathrm{~N}$ shifts of $\mathbf{1}$ and $\mathbf{1}^{\prime}$ immediately after the start of the reaction with control 
samples (no DNA added to ${ }^{15} \mathrm{~N}-\mathbf{1}$ and $\mathbf{- 1}^{\prime}$ in $15 \mathrm{mM}$ phosphate buffer). These results are summarized in Table 1 and compared with those of $1,0,1 / t, t, t,{ }^{11}$ and $1,1 / t, t .{ }^{10}$ For both $\mathbf{1}$ and $\mathbf{1}^{\prime}$ the ${ }^{1} \mathrm{H}$ and ${ }^{15} \mathrm{~N}$ shifts of the $\mathrm{Pt}-\mathrm{NH}_{3}$ groups are strongly deshielded in comparison with the control samples, consistent with $\mathrm{H}$-bonding interactions between the $\mathrm{Pt}-{ }^{15} \mathrm{NH}_{3}$ groups and the phosphate backbone of the DNA. The ${ }^{1} \mathrm{H}$ shifts are slightly more strongly deshielded $\left(\Delta \delta{ }^{1} \mathrm{H}=0.07(\mathbf{1}), 0.09\right.$ $\left.\left(\mathbf{1}^{\prime}\right)\right)$ in comparison to both $1,0,1 / t, t, t$ and $1,1 / t, t\left(\Delta \delta^{1} \mathrm{H}=0.05\right)$, whereas the ${ }^{15} \mathrm{~N}$ shifts are similar in all cases $\left(\Delta \delta^{15} \mathrm{~N} \sim 0.3 \mathrm{ppm}\right)$. An interesting difference is observed for the $\mathrm{Pt}-\mathrm{NH}_{2}$ groups. For ${ }^{15} \mathrm{~N}-\mathbf{1}^{\prime}$ a single ${ }^{1} \mathrm{H} /{ }^{15} \mathrm{~N}$ cross-peak is observed in the $\mathrm{Pt}-\mathrm{NH}_{2}$ region $(\delta 5.10 /-47.1)$ which is more strongly deshielded in the ${ }^{1} \mathrm{H}$ dimension $(\Delta \delta=0.12)$ in comparison to both $1,0,1 / t, t, t$ and $1,1 / t, t$ $(\Delta \delta=0.02)$, which also show only a single (pre-associated) environment. On the other hand, in the case of ${ }^{15} \mathrm{~N}-1$ three distinct cross-peaks are observed $(\delta 5.07 /-47.6,5.10 /-47.6$ and 5.10/-47.1) (see Figure S3) which are assigned to three inequivalent environments of the $\mathrm{Pt}-{ }^{15} \mathrm{NH}_{2}$ groups of $\mathbf{1}$, pre-associated with duplex I. In the absence of DNA, under the same conditions, only one crosspeak is observed for the dichloro species of $1 .{ }^{33}$ The ${ }^{1} \mathrm{H}$ shifts of these cross-peaks are strongly deshielded ( $\Delta \delta=0.09-0.12)$ in comparison to $1,0,1 / t, t, t$ and two of the cross-peaks exhibit a significant shielding in the ${ }^{15} \mathrm{~N}$ dimension $(\Delta \delta=0.6)$, further suggesting that the $\mathrm{Pt}-\mathrm{NH}_{2}$ groups are in different chemical environments in these pre-associated forms of $\mathbf{1}$. As time progresses and $\mathbf{1}$ proceeds to bind to duplex $\mathbf{I}$, these cross-peaks decrease in intensity and eventually disappear but have different time dependent profiles. The cross-peak at $\delta 5.07 /-47.6$ is the first to disappear (after $9 \mathrm{~h}$ ), followed by that at $\delta 5.10 /-47.6(\mathrm{ca} .12 \mathrm{~h}$ ) and finally the cross-peak at $\delta 5.10 /-47.1$ (ca. $18 \mathrm{~h}$ ). Interestingly, the unusually shielded ${ }^{15} \mathrm{~N}$ shift $(\delta-47.6)$ is observed also for the monofunctional adduct (see below), suggesting that conversion to these pre-associated forms may be a precursor to monofunctional adduct formation. That different $\mathrm{NH}_{2}$ environments are observed 
for $\mathbf{1}$ and not $\mathbf{1}^{\prime}$ is interesting as it suggests that $\mathbf{1}$ experiences an environment that is at least as heterogeneous as for $\mathbf{1}^{\prime}$ in the pre-covalent phase, despite less significant changes observed for the DNA adenine $\mathrm{H} 2$ protons and the $(2 / 5) \mathrm{CH}_{2}$ groups of the polyamine linker.

Aquation Step. In reactions of both ${ }^{15} \mathrm{~N}-\mathbf{1}$ and $\mathbf{- 1}$ with duplex $\mathbf{I}$, the monoaqua monochloro species $\left(\mathbf{2} / \mathbf{2}^{\prime}\right)$ accounts for $\sim 2-3 \%$ of the total species in solution after $c a .5 \mathrm{~h}$, based on the relative intensities of the cross-peaks for the $\mathrm{Pt}-\mathrm{NH}_{3}$ resonance of the $\left\{\mathrm{PtN}_{3} \mathrm{O}\right\}$ groups. These resonances have almost identical chemical shifts ( $\delta$ 4.22/-61.8 (2); 4.23/-61.8 (2’), Figure 1) and show a pronounced downfield shift $\left(\Delta \delta^{1} \mathrm{H}=0.19(2), 0.20\left(\mathbf{2}^{\prime}\right) ;{ }^{15} \mathrm{~N} 0.4\right)$, compared to control samples, indicating a stronger electrostatic interaction with the duplex than for $\mathbf{1} \mathbf{1}^{\prime}$, as a consequence of the increased charge $(+2)$. The ${ }^{1} \mathrm{H} /{ }^{15} \mathrm{~N}$ shifts of these resonances, and the extent of the deshielding, is very similar to that observed in the reaction with $1,0,1 / t, t, t$ (Table 1$).{ }^{11}$ The small difference in the chemical shift in the ${ }^{1} \mathrm{H}$ dimension $(\Delta \delta \sim 0.04)$ may be due to slight differences in the $\mathrm{pH}$ of the solutions and is considered insignificant. As for the previous reactions of duplex I with $1,1 / t, t$ and $1,0,1 / t, t, t$, the cross-peaks for the $\mathrm{Pt}-\mathrm{NH}_{3}$ resonance of the non-aquated $\left\{\mathrm{PtN}_{3} \mathrm{Cl}\right\}$ groups are assumed to be concealed beneath the cross-peaks for the parent dichloro species $\left(\mathbf{1}^{\prime} \mathbf{1}^{\prime}\right)$. In the $\mathrm{Pt}-$ ${ }^{15} \mathrm{NH}_{2}$ region, no cross-peaks corresponding to the $\left\{\mathrm{PtN}_{3} \mathrm{O}\right\}$ moiety of $\mathbf{2} / \mathbf{2}^{\prime}$ are observed due to close proximity to the residual ${ }^{1} \mathrm{H}_{2} \mathrm{O}$ resonance.

Monofunctional Binding Step. ${ }^{1} \mathrm{H},{ }^{15} \mathrm{~N}$ peaks for the monofunctional adduct $\left(\mathbf{3}^{\prime} \mathbf{3}^{\prime}\right)$ were observed slightly later for $\mathbf{1}(1.4 \mathrm{~h})$ than $\mathbf{1}^{\prime}(0.7 \mathrm{~h})$. The ${ }^{1} \mathrm{H} /{ }^{15} \mathrm{~N}$ shifts of the $\mathrm{Pt}-\left(\mathrm{NH}_{3}\right)_{2}$ group bound to guanine N7 (peaks 3a/3'a, Figure 1) are almost identical for the reactions of $\mathbf{1}(\delta 4.29 /-60.7)$ and $\mathbf{1}^{\prime}(\delta 4.30 /-60.7)$ and also those formed by both $1,0,1 / t, t, t(4.29 /-60.6)^{11}$ and $1,1 / t, t(\delta 4.29 /-$ $60.8)^{10}$ with duplex $\mathbf{I}$. The peaks are shifted significantly in both dimensions compared to the noncovalently bound compounds and are indicative of very similar H-bonded environments for the 
Pt- $\left(\mathrm{NH}_{3}\right)_{2}$ groups in the different complexes, which are not influenced by differences in the polyamine linkers. The ${ }^{1} \mathrm{H} /{ }^{15} \mathrm{~N}$ shifts of the cross-peaks for the $\mathrm{Pt}-\left(\mathrm{NH}_{3}\right)_{2}$ groups of the unbound $\left\{\mathrm{PtN}_{3} \mathrm{Cl}\right\}$ end of the monofunctional adducts are also virtually identical for the four complexes (Table 1$)$. In the case of $\mathbf{1}$, the cross-peak ( $\delta 3.94 /-64.2$, peak 3b, Figure 1$)$ appears as a shoulder to the parent dichloro cross-peak. The slight deshielding in the ${ }^{1} \mathrm{H}$ dimension $\left(\Delta \delta{ }^{1} \mathrm{H}=0.02\right)$ is identical to that observed for the monofunctional adducts of $1,1 / t, t^{10}$ and $1,0,1 / t, t, t^{11}$ with duplex $\mathbf{I}$ (as well as other DNA sequences) ${ }^{11}$ and is attributed to similar electrostatic interactions between the uncoordinated $\left\{\mathrm{PtN}_{3} \mathrm{Cl}\right\}$ group and the DNA. ${ }^{10,11}$ This characteristic deshielding is not observed for $\mathbf{1}^{\prime}$ (although the ${ }^{1} \mathrm{H} /{ }^{15} \mathrm{~N}$ shifts of $\mathbf{3}$ and $\mathbf{3}^{\prime}$ are identical), due to the slightly stronger deshielding observed for the ${ }^{1} \mathrm{H}$ shift of the $\mathrm{Pt}-\left(\mathrm{NH}_{3}\right)_{2}$ groups of the parent dichloro complex (see above) which means that the cross-peaks for $\mathbf{3} \mathbf{b}^{\prime}$ and $\mathbf{1}^{\prime}$ are coincident (Figure $1 \mathbf{b}$ ). This peak overlap precludes a full kinetic analysis of the reaction of $\mathbf{1}^{\prime}$ and duplex I (see below).

The cross-peaks observed for the $\mathrm{Pt}-\mathrm{NH}_{2}$ groups are also similar (but not identical) for the monofunctional adducts formed by $\mathbf{1}$ and $\mathbf{1}^{\prime}$, and also those formed by $1,1 / t, t$ and $1,0,1 / t, t, t$ (Table $1)$. For 1, two cross-peaks ( $\delta 5.13 /-47.1$ and 5.13/-47.5) (Figure 1a) are observed which may be assigned to the monofunctional species $\mathbf{3}$ based on their time dependent behavior. They are not observed in spectra recorded at early time points and are seen to first increase in intensity then decrease until they are no longer visible. Two similar cross-peaks ( $\delta 5.14 /-47.0$ and $\delta 5.12 /-47.6)$ are observed during the reaction with $\mathbf{1}^{\prime}$, assignable to the monofuctional adduct $\mathbf{3}^{\prime}$. It is not possible to unequivocally assign these peaks more specifically to the different $\mathrm{Pt}-\mathrm{NH}_{2}$ groups of the monofunctional species. However, the presence of two distinct cross-peaks suggests that in both cases the $\mathrm{Pt}-{ }^{15} \mathrm{NH}_{2}$ group corresponding to the unbound end, $\left\{\mathrm{PtN}_{3} \mathrm{Cl}\right\}$, of the monofunctionally bound species is in a distinctly different environment to that of the dichloro 
species. For $1,0,1 / t, t, t$, only one crosspeak ( $\delta 5.12 /-46.9)$ was observed, corresponding to the guanine N7 bound end of the monofunctional species and the cross-peak corresponding to the unbound end $\left\{\mathrm{PtN}_{3} \mathrm{Cl}\right\}$ was concealed beneath that of the dichloro species. ${ }^{11}$

The monofunctional binding of ${ }^{15} \mathrm{~N}-\mathbf{1}$ and $\mathbf{- 1}^{\prime}$ to duplex $\mathbf{I}$ was also monitored in the aromatic region of the ${ }^{1} \mathrm{H}$ NMR spectra recorded over the course of the reaction (Figure 2). Resonances at $\delta$ $8.54(3)$ and $\delta 8.50\left(3^{\prime}\right)$ follow the time-dependent profiles of the cross-peaks corresponding to the monofunctional species in the $\mathrm{Pt}-{ }^{15} \mathrm{NH}_{3}$ region of the $2 \mathrm{D}\left[{ }^{1} \mathrm{H},{ }^{15} \mathrm{~N}\right]$ HSQC spectra and are assignable to the $\mathrm{H} 8$ of the coordinated $\mathrm{G}$ residues.

Based on the intensities of the crosspeaks in the $\mathrm{Pt}-{ }^{15} \mathrm{NH}_{3}$ region of the $2 \mathrm{D}\left[{ }^{1} \mathrm{H},{ }^{15} \mathrm{~N}\right] \mathrm{HSQC}$ spectra, the concentration of the monofunctional species, $\mathbf{3}$, reaches a maximum of $27 \%$ of the total species in solution after $10.5 \mathrm{~h}$, whereas $\mathbf{3}^{\prime}$ reaches a maximum intensity of $23 \%$ after approximately $7 \mathrm{~h}$.

Formation of the 1,4-Interstrand Cross-Link. A significant difference between the formation of 1,4-interstrand cross-links by $1,1 / t, t$ and $1,0,1 / t, t, t$ with duplex $\mathbf{I}$ is that whereas the dinuclear complex forms predominantly one adduct, there was evidence for two distinct conformers (ratio 2.6:1) of the 1,4-cross-link formed by $1,0,1 / \mathrm{t}, \mathrm{t}, \mathrm{t}$. These differences were evident from the pattern of cross-peaks in the Pt- $\mathrm{NH}_{3}$ region of the $2 \mathrm{D}\left[{ }^{1} \mathrm{H},{ }^{15} \mathrm{~N}\right] \mathrm{HSQC}$ NMR spectra, as well as from the aromatic region of the ${ }^{1} \mathrm{H}$ NMR spectrum, where a single GH8 resonance $(\delta 8.59)$ was observed for the 1,4-cross-link formed by $1,1 / t, t$, but two peaks of unequal intensity (at $\delta 8.60$ and 8.59 ) were observed for the in the case of $1,0,1 / t, t, t$. Comparison with these results provides evidence for several non-discrete conformers of the 1,4-cross-links formed by both $\mathbf{1}$ and $\mathbf{1}^{\prime}$ with duplex $\mathbf{I}$, rather than two distinct conformers formed by $1,0,1 / t, t, t$. 
In the case of $\mathbf{1}$, evidence for several conformers of the bifunctional adduct is obtained from the aromatic region of the ${ }^{1} \mathrm{H}$ NMR spectra after completion of the reaction (Figure 2a), where there is a major peak at $\delta 8.61$, but also numerous other smaller resonances $(\delta 8.57-8.60)$ assignable to $\mathrm{H} 8$ protons of the platinated guanine residues. In the $\mathrm{Pt}-\mathrm{NH}_{3}$ region of the $2 \mathrm{D}\left[{ }^{1} \mathrm{H},{ }^{15} \mathrm{~N}\right] \mathrm{HSQC}$ spectra, ${ }^{1} \mathrm{H},{ }^{15} \mathrm{~N}$ cross-peaks assignable to the bifunctional 1,4-cross-link (4) were first visible after ca. 3.4 h. A cross-peak ( $\delta 4.32 /-61.0)$ first appears as a shoulder to the cross-peak (3a) assigned to Pt- $\left(\mathrm{NH}_{3}\right)_{2}$ group bound to guanine $\mathrm{N} 7$ in the monofunctional adduct (Figure 1a). On completion of the reaction three groups of cross-peaks are observed in this region, assignable to different $\mathrm{Pt}-\mathrm{NH}_{3}$ environments in the 1,4-interstrand cross-link (4). For 1,0,1/t,t,t, three sets of cross-peaks were observed also, but were more clearly defined than the present case and assignable to four different $\mathrm{H}$-bonding environments for the $\mathrm{Pt}-\mathrm{NH}_{3}$ groups in each of the two distinct conformers (X and Y). ${ }^{11}$ The $\mathrm{Pt}-\mathrm{NH}_{3}$ 'A' groups are assumed to form H-bonds to the DNA phosphate backbone, whereas the 'B' groups form $\mathrm{H}$-bonds to the $\mathrm{O} 6$ atom of the platinated guanine residues:

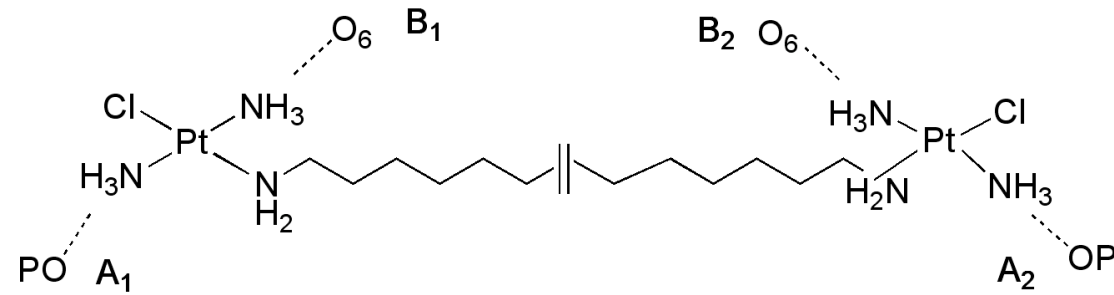

An important similarity observed here for the reaction of $\mathbf{1}$ with duplex $\mathbf{I}$, is the presence of a pair of sharp, strongly deshielded, cross-peaks ( $\delta$ 4.54/-59.7 and 4.57/-59.7) that strongly resemble a pair of cross-peaks observed in the analogous reaction with $1,0,1 / t, t, t(\delta 4.51 /-59.9$ and 4.57/-59.7), which were assigned to the $A_{1}$ and $A_{2} N_{3}$ groups of the minor (Y) conformer. The other cross-peaks in this region are broader than occurred for the $1,0,1 / t, t, t$ case and are clustered in two groups $(\sim \delta 4.43 /-60.4$ and $\delta 4.32 /-61.0)$. They are assigned to the $\mathrm{B}_{1}$ and $\mathrm{B}_{2} \mathrm{NH}_{3}$ groups of this conformer $(\mathrm{Y})$, together with the $\mathrm{A}$ and $\mathrm{B} \mathrm{NH} 3$ groups of other conformers $(\mathrm{X})$. In this case $\mathrm{X}$ 
is not a discrete conformer but based on the ${ }^{1} \mathrm{H}$ NMR spectrum (Figure 2a) a collection of several conformers.

In the case of $\mathbf{1}^{\prime}$, the aromatic region of the ${ }^{1} \mathrm{H}$ NMR spectrum after completion of the reaction (Figure $2 \mathrm{~b}$ ), shows three broad resonances $(\delta 8.54, \delta 8.59$ and $\delta 8.61)$ assignable to $\mathrm{H} 8$ protons of platinated guanine residues and again indicative of several conformers of the 1,4-cross-link. The peaks are much broader than observed for the other cross-linked adducts of $\mathbf{I}$, suggesting that these cross-links may be more fluxional, allowing the Pt groups more freedom of movement, thus broadening the resonances. In the $\mathrm{Pt}-\mathrm{NH}_{3}$ region of the $2 \mathrm{D}\left[{ }^{1} \mathrm{H},{ }^{15} \mathrm{~N}\right] \mathrm{HSQC}$ spectra (Figure 1b), the formation of the bifunctionally cross-linked adduct, $\mathbf{4}^{\prime}$, was apparent after $5.3 \mathrm{~h}$ as a cross-peak downfield from the cross-peak assigned to the $\left\{\mathrm{PtN}_{4}\right\}$ end of the monofunctional species, $3^{\prime}$. As for the reactions with 1 and 1,0,1/t,t,t, three groups of cross-peaks are observed on completion of the reaction, which include a sharp pair of cross-peaks $(\delta 4.53 /-59.8$ and $\delta 4.58 /-59.9$; see Figure 1b) which are assigned to the $A_{1}$ and $A_{2} N_{3}$ groups of the $Y$ conformer, based on the similarity of their ${ }^{1} \mathrm{H} /{ }^{15} \mathrm{~N}$ chemical shifts to those observed in the analogous reaction with $1,0,1 / t, t, t .{ }^{11}$ The two other broad sets of cross-peaks $(\sim \delta 4.30 /-60.8$ and $\delta 4.37 /-60.8)$ are assigned to the $\mathrm{B}_{1}$ and $\mathrm{B}_{2} \mathrm{NH}_{3}$ groups of conformer $\mathrm{Y}$ as well as the $\mathrm{A}$ and $\mathrm{B} \mathrm{NH}_{3}$ groups of the other non-discrete conformers (X). Table 2 shows a comparison of the ${ }^{1} \mathrm{H} /{ }^{15} \mathrm{~N}$ chemical shifts of the $\mathrm{Pt}-{ }^{15} \mathrm{NH}_{3}$ groups of the different conformers of the 1,4-cross-links formed by $\mathbf{1}, \mathbf{1}^{\prime}$ and $1,0,1 / t, t, t$. In all cases the Pt- $\mathrm{NH}_{3}$ 'A' groups in the different conformers ( $\mathrm{Y}$ and others) have very similar chemical shifts in both ${ }^{1} \mathrm{H}$ and ${ }^{15} \mathrm{~N}$ dimensions, suggesting similar $\mathrm{H}$-bonding interactions between the $\mathrm{Pt}-{ }^{15} \mathrm{NH}_{3}$ groups and the phosphate backbone of duplex $\mathbf{I}$. For the $\mathrm{Pt}-\mathrm{NH}_{3}$ 'B' groups in the case of $\mathbf{1}^{\prime}$ the ${ }^{1} \mathrm{H}$ and ${ }^{15} \mathrm{~N}$ chemical shifts are almost identical to those found for both conformers of the $1,0,1 / t, t, t$ adduct. On the other hand, for $\mathbf{1}$ the $\mathrm{Pt}-{ }^{15} \mathrm{NH}_{3}$ the 'B' environments in all conformers are significantly 
deshielded in both the ${ }^{1} \mathrm{H}$ and ${ }^{15} \mathrm{~N}$ dimensions $\left(\Delta \delta{ }^{1} \mathrm{H}=0.06,{ }^{15} \mathrm{~N} \sim 0.5\right)$. This suggests that for 1 the H-bonding interactions between the $\mathrm{Pt}-{ }^{15} \mathrm{NH}_{3}$ groups and the $\mathrm{O} 6$ atoms of the platinated guanine residues may be stronger than those found for $1,0,1 / t, t, t$ and $\mathbf{1}^{\prime}$.

\section{(Insert Table 2 here)}

For the reaction of $1,0,1 / t, t, t$ with duplex $\mathbf{I}$, evidence for the two discrete conformers was found from the observation of two sets of ${ }^{1} \mathrm{H}$ NMR resonances assignable to the linker methylene groups 2 and 5. One set ( $\delta 1.69$ and 1.66) was assigned to the major $(\mathrm{X})$ conformer and the other $(\delta 1.74$, 1.59 and 1.85) assigned to the minor (Y) conformer. ${ }^{11}$ For the reactions of $\mathbf{1}$ and $\mathbf{1}^{\prime}$ with duplex $\mathbf{I}$, numerous resonances were observed in this region (Figure S1) that cannot be assigned specifically to any conformer. Interestingly, these linker- $\mathrm{CH}_{2}$ resonances are more shielded for the bifunctional adduct of $\mathbf{1}^{\prime}$.

A notable feature of the reaction of $1,1 / t, t$ and $1,0,1 / t, t, t$ with duplex $\mathbf{I}$ was the gradual and irreversible transformation of peaks in the $\mathrm{Pt}_{-} \mathrm{NH}_{2}$ region, from an initially formed conformer(s) to product conformer(s). ${ }^{10,11}$ For the initially formed adducts, the ${ }^{1} \mathrm{H} /{ }^{15} \mathrm{~N}$ shifts of the $\mathrm{Pt}-\mathrm{NH}_{2}$ protons were similar to those of the pre-associated complex and the monofunctional adducts and indicate environments where the $\mathrm{NH}_{2}$ protons have no contacts except with solvent. For the final product conformer(s) a range of distinct $\mathrm{NH}_{2}$ environments were found, indicative of interactions between the $\mathrm{NH}_{2}$ protons and the DNA as a result of changes in the DNA conformation. Duplex $\mathbf{I}$ has an alternating purine-pyrimidine sequence, and we have suggested that the observed changes could be indicative of a $\mathrm{B} \rightarrow \mathrm{Z}$ conformational change. ${ }^{10,11} \mathrm{~A}$ similar behavior is observed here for the 1,4crosslinks formed by both $\mathbf{1}$ and $\mathbf{1}^{\prime}$. In the case of $\mathbf{1}$ the first ${ }^{1} \mathrm{H},{ }^{15} \mathrm{~N}$ peaks assignable to the bifunctional adduct were visible in the $\mathrm{Pt}_{-} \mathrm{NH}_{2}$ region after $c a .5 \mathrm{~h}$ and the initial peak $(\delta 5.18 /-$ 47.5) lies very close to that of the monofunctional adduct. New peaks with a ${ }^{15} \mathrm{~N}$ shift at $\delta-45.5$ 
were first visible around $8.5 \mathrm{~h}$. At the end of the reaction cross-peaks centered at the two ${ }^{15} \mathrm{~N}$ shifts $(\delta-47.5$ and -45.5$)$ both cover a wide chemical shift range in the ${ }^{1} \mathrm{H}$ dimension (Figure 1a). For the reaction with $\mathbf{1}^{\prime}$ the $\mathrm{Pt}-\mathrm{NH}_{2}$ cross-peaks of the final bifunctional adduct have a significantly diminished intensity compared to those of $\mathbf{1}$ but it is evident that there are similarly cross-peaks centered at the same two ${ }^{15} \mathrm{~N}$ shifts $(\delta-47.5$ and -45.5$)$, which are spread out in a similar fashion in the ${ }^{1} \mathrm{H}$ dimension (Figure 1b). The final intensity ratio of the peaks at the two ${ }^{15} \mathrm{~N}$ shifts is $\delta-$ $47.5\left(52 \% \mathbf{1}, 63 \% \mathbf{1}^{\prime}\right), \delta-45.5\left(48 \% \mathbf{1}, 37 \% \mathbf{1}^{\prime}\right)$. For $1,1 / t, t^{10}$ the cross-peaks for the final product conformers of the 1,4 cross-link with I were centered at three ${ }^{15} \mathrm{~N}$ shifts : $\delta-47.5(22 \%), \delta-48.4$ $(46 \%), \delta-45.5(31 \%)$ which differ slightly from those of the $1,0,1 / t, t, t$ case $^{11}: \delta-47.4(27 \%), \delta-$ $46.5(32 \%), \delta-45.3(41 \%)$.

Central $-{ }^{15} \mathbf{N H}_{2}-$ Region. To examine how the polyamine moiety itself associates (and preassociates) with duplex $\mathbf{I}$, we attempted to monitor the behavior of the central $-{ }^{15} \mathrm{NH}_{2}-$ groups by $\left[{ }^{1} \mathrm{H},{ }^{15} \mathrm{~N}\right]$ HSQC NMR spectroscopy. The observation of these ${ }^{1} \mathrm{H} /{ }^{15} \mathrm{~N}$ cross-peaks is $\mathrm{pH}$ dependent due to the exchange between the protonated and deprotonated forms. For 1, the cross-peak for the central $-{ }^{15} \mathrm{NH}_{2}$ - group is visible below $\mathrm{pH} 5.7,{ }^{33}$ whereas for $\mathbf{1}^{\prime}$ the ${ }^{1} \mathrm{H} /{ }^{15} \mathrm{~N}$ resonance for the central ethylenediamine moiety is not observed above $\mathrm{pH} 4.1$, attributed to the close proximity of the two ${ }^{15} \mathrm{NH}_{2}$ groups and ${ }^{1} \mathrm{H}$ exchange between the two ${ }^{15} \mathrm{~N}$ atoms broadening the signal beyond detection. ${ }^{33}$ At $\sim \mathrm{pH} \mathrm{5.4,} \mathrm{at} \mathrm{which} \mathrm{the} \mathrm{experiments} \mathrm{were} \mathrm{carried} \mathrm{out,} \mathrm{only} \mathbf{1}$ (where there is only one central $-\mathrm{NH}_{2}-$ group-) could be examined in detail (Figure 4).

\section{(Insert Figure 4 here)}

A cross-peak observed at $\delta 7.96 / 25.5$ is assigned to the dichloro species (1) and the ${ }^{15} \mathrm{~N}$ shift is in agreement with previous studies on related free polyamines. ${ }^{37-39}$ The cross-peak is slightly deshielded $(\Delta \delta=0.02)$ in the ${ }^{1} \mathrm{H}$ dimension compared to a control sample of $\mathbf{1}(\delta 7.94 / 25.5)$ in the 
absence of DNA at the same $\mathrm{pH}$ (5.4), correlating with the slight chemical shift changes in the aromatic region of the ${ }^{1} \mathrm{H}$ NMR spectra (Figure 3a), and indicative of weak electrostatic interactions between the central $-{ }^{15} \mathrm{NH}_{2}-$ protons and the DNA. A cross-peak at $\delta 8.00 / 25.1$ assignable to the monofunctional species $(\mathbf{3})$ was first visible $1 \mathrm{~h}$ after the start of the reaction and was no longer observed after $26 \mathrm{~h}$. Two cross-peaks of low intensity at $\delta 8.07 / 25.5$ and $\delta 8.04 / 25.1$ are assignable to the central $-{ }^{15} \mathrm{NH}_{2}-$ group of the polyamine in the bifunctional cross-linked adduct. As the reaction proceeds, these cross-peaks gradually disappear (Figure 4), most likely attributable to an increase in $\mathrm{pH}$ as the final $\mathrm{pH}$ was 5.7 on completion of the reaction. The increased deshielding of the resonances in the ${ }^{1} \mathrm{H}$ dimension on formation of monofunctional $(\Delta \delta$ $=0.04)$ and bifunctional $(\Delta \delta=0.08-0.11)$ adducts in consistent with the formation of hydrogen bonds between the NH protons and the DNA.

Kinetic Analysis. For the purposes of the kinetic fits of the reactions of $\mathbf{1}$ and $\mathbf{1}^{\prime}$ with duplex I the concentration of species present at each time point were obtained from the relative volumes of peaks in the Pt-NH$H_{3}$ region, as described previously for the reactions of $1,1 / t, t$ and $1,0,1 / t, t, t$ with this sequence. ${ }^{10,11}$ All reactions were assumed to be irreversible. As for the reaction with $1,0,1 / t, t, t$, no peak was observed for a monofunctional aqua species in either reaction, thus the models used only incorporated the products directly formed by monofunctional $(\mathrm{G} / \mathrm{Cl}$ ) species (see Scheme 1). Two different kinetic models were used. In model I, all conformers of the 1,4-cross-link were treated as single product. In model II, the Y conformer was treated as a discreet conformer whilst the $\mathrm{X}$ conformer was treated as a mixture of conformers that are indistinguishable. In the case of $\mathbf{1}^{\prime}$, a full kinetic analysis for the reaction was not possible due to the overlap of the cross-peaks for both ends of the monofunctional adduct $\left(\mathbf{3}^{\prime}\right)$. The cross-peak for the unbound $\left\{\mathrm{PtN}_{3} \mathrm{Cl}\right\}$ end of $\mathbf{3}^{\prime}$ is obscured by that of the parent dichloro compound, and as the reaction proceeds, the cross-peak for 
the guanine $\mathrm{N} 7$ bound end becomes overlapped by cross-peaks corresponding to bifunctional adduct, $\mathbf{4}^{\prime}$ (see Figure $1 \mathrm{~b}$ ). The change in concentration of species $v s$. time for the monofunctional species was calculated by using a combination of intensities of both cross-peaks. The data points for the first $15 \mathrm{~h}$ were calculated based on the intensity of the cross-peak ( $\left.\mathbf{3}^{\prime} \mathbf{a}\right)$ corresponding to the monofunctionally bound $\left\{\mathrm{PtN}_{4}\right\}$ end of $\mathbf{3}^{\prime}$. No data points were used between 15 and $40 \mathrm{~h}$ time points, after which the intensities were calculated based on the intensity of the unbound $\left\{\mathrm{PtN}_{3} \mathrm{Cl}\right\}$ end of $\mathbf{3}^{\prime}$ (after the cross-peak $\mathbf{3}^{\prime} \mathbf{b}$ is no longer overlapped with that of $\mathbf{1}^{\prime}$ ). The rate constants obtained from the two kinetic models for the two reactions are listed in Table 3 and the computer best fits for the rate constants are shown in Figure 5.

\section{(Insert Table 3 and Figure 5 here)}

For both reactions the pseudo-first-order rate constants for the aquation process are significantly lower than for the reaction of 1,0,1/t,t,t with duplex I under identical conditions (Table 3). This difference is greater for $\mathbf{1}^{\prime}$ (1.7 fold lower) than $\mathbf{1}$ (1.5 fold lower) and the overall trend is consistent with the results of aquation studies carried out in the absence of DNA (Table 3). ${ }^{33}$ As found for 1,0,1/t,t,t, pre-association has a strong influence on the aquation step, as can be seen from a comparison of the value of the pseudo-first-order rate constants with those of the forward (aquation) rate constants for the three compounds under the same conditions of $\mathrm{pH}$ and ionic strength in the absence of DNA (Table 3). For 1 and $1,0,1 / t, t, t$ the value of $k_{\mathrm{H}}$ is 2.7 fold lower in the presence of DNA, and this difference is greater than occurs for $\mathbf{1}^{\prime}$ (1.7 fold lower). The rate constant for the formation of the monofunctional species is 3.6 fold higher for $\mathbf{1}$ compared to $1,0,1 / t, t, t .{ }^{11}$ Thus, it can be said that it is the slower aquation process that results in $\mathbf{1}$ taking longer (57 h) to form the 1,4-interstand bifunctional adduct with duplex I compared to 1,0,1/t,t,t (48 h), given that the rate constants for closure of the monofunctional adduct $\left(k_{\mathrm{CH}}\right)$ are comparable (Table 
3). In the case of $\mathbf{1}^{\prime}$, while it is not possible to obtain the rate constant for the monofunctional binding step, comparison of the reaction profiles suggests that monofunctional adduct formation may occur slightly faster than for $\mathbf{1}$, since the monofunctional species reaches a maximum concentration more rapidly ( $7 \mathrm{~h}$ vs. $10.5 \mathrm{~h})$, despite the slower aquation step. However, this observation could equally result from a larger rate constant for the closure of the bifunctional cross-link in the case of $\mathbf{1}^{\prime}$, as is observed from a comparison of the rate constants $\left(k_{\mathrm{CH}}\right)$ in Table 3. The overall reaction is complete after $54 \mathrm{~h}$, which is similar to that of $\mathbf{1}$ and consistent with aquation being the rate-limiting step in the formation of both monofunctional and bifunctional adducts. Interestingly, for both PPCs closure to give the discrete minor (Y) conformer of the 1,4cross-link occurs significantly slower (2.3-4.6 fold) than for the other conformers, and the trend is similar to that observed for the minor conformer formed by $1,0,1 / t, t, t .^{11}$

\section{DISCUSSION}

There are numerous accounts of potential anticancer therapeutic metal complexes that incorporate polyamines into their structure. Second generation polyamine derivatives of $1,0,1 / t, t, t$ that incorporate a H-bonding motif, and exploit the fact that polyamines such as spermine and spermidine are inherent in cellular processes offer the possibility a new suite of anticancer complexes that enhances the biological profile of $1,0,1 / t, t, t$.

The terminal $\left\{\mathrm{PtN}_{3} \mathrm{Cl}\right\}$ moieties of $\mathbf{1}$ and $\mathbf{1}^{\prime}$ are spaced sufficiently far apart that they would not be expected to influence each other's behavior, but previous aquation studies have shown that there are remarkable differences (even between both complexes) in the rate constants for the aquation and anation steps in comparison to $1,0,1 / t, t, t$ and the dinuclear $1,1 / t, t .^{33}$ Interestingly, the $\mathrm{p} K_{\mathrm{a}}$ values for the aquated forms of both PPCs are significantly higher when compared to 1,0,1/t,t,t 
and $1,1 / t, t\left(5.92\right.$ vs. 5.62).$^{33}$ Thus it appears that the central non-coordinated amine groups affect the behavior of the terminal Pt coordination spheres and the higher $\mathrm{p} K_{\mathrm{a}}$ values of $\mathbf{1}$ and $\mathbf{1}^{\prime}$ have been attributed to the formation of macrochelates between the central $\mathrm{NH}_{2}$ groups and the $\left\{\mathrm{PtN}_{3} \mathrm{O}\right\}$ groups of the aquated species..$^{33}$

Previous work has shown that the aquation rate of $1,0,1 / t, t, t$ (and $1,1 / t, t$ ) are altered in the presence of DNA, ${ }^{11}$ with the hypothesis being that the lower aquation rate constant may stem from pre-association between the Pt complex and the DNA. This pre-association restricts access of the solvent to the coordination sphere, thus obstructing the formation of a 5-membered transition state necessary for substitution reactions such as aquation. It is interesting that the lowering of the aquation rate constants for $\mathbf{1}$ and $1,0,1 / t, t, t$ in the presence of DNA are comparable in magnitude and more pronounced than for $\mathbf{1}^{\prime}$, as all three complexes show similar H-bonding interactions for the $\mathrm{Pt}-{ }^{15} \mathrm{NH}_{3}$ and $\mathrm{Pt}-{ }^{15} \mathrm{NH}_{2}$ groups with duplex $\mathbf{I}$.

Previously it has been reported that a stronger pre-association in the minor groove by $1,0,1 / t, t, t$ alters the approach of the $\mathrm{Pt}-\mathrm{Cl}$ group to the guanine $\mathrm{N} 7$ binding site for monofunctional binding compared to $1,1 / t, t$ (which does not pre-associate in the minor groove and binds monofunctionally faster compared to $1,0,1 / t, t, t)$. The higher rate constant observed for $\mathbf{1}\left(0.87 \mathrm{M}^{-1} \mathrm{~s}^{-1}\right)$ compared to $1,0,1 / t, t, t\left(0.25 \mathrm{M}^{-1} \mathrm{~s}^{-1}\right)$ and the quantitatively weaker electrostatic interactions (based on the magnitude of the changes in chemical shifts of adenine $\mathrm{H} 2$ protons) are consistent with this view. The rate constant for the monofunctional binding of $\mathbf{1}$ to duplex $\mathbf{I}$ is almost 2-fold higher than that observed for $1,1 / t, t\left(0.47 \mathrm{M}^{-1} \mathrm{~s}^{-1}\right)$ and perhaps even higher in the case of $\mathbf{1}^{\prime}$. The comparison is not strictly valid, however, as although all four reactions with duplex I were carried out under identical conditions ( $\mathrm{pH}$, ionic strength and temperature), the $\mathrm{p} K_{\mathrm{a}}$ values for the aquated forms of $\mathbf{1}$ and $\mathbf{1}^{\prime}$ are $0.3 \mathrm{pK}$ units higher. ${ }^{33}$ This difference means that there will be a greater proportion of the 
more reactive aquated species (compared to the less reacted hydroxo species) present in the solution than for $1,1 / t, t$ and $1,0,1 / t, t, t$ under the same reaction conditions. On the other hand the $\mathrm{p} K_{\mathrm{a}}$ values measured for the free complexes may be irrelevant to the current situation. It seems unlikely that the macrochelates of the central $\mathrm{NH}_{2}$ groups of $\mathbf{1}$ and $\mathbf{1}^{\prime}$ with the respective aqua ligands would be maintained when non-covalently bound to DNA.

Biophysical methods have compared the global DNA binding profiles of spermidine and spemine-linked dinuclear platinum complexes and most recently $\mathbf{1}^{\prime}$ to those for $1,1 / t, t$ and $1,0,1 / t, t, t .^{22,28}$ In contrast to the kinetic studies described here, the binding of all polyamine complexes to the DNA was very fast relative to the simple alkyl linked complex $1,1 / t, t$. Increasing the salt concentration slowed but did not inhibit the binding. It is possible that the polymer induces stronger recognition by electrostatic and H-bonding, explaining the differences. In the ${ }^{1} \mathrm{H}$ and $2 \mathrm{D}$ $\left[{ }^{1} \mathrm{H},{ }^{15} \mathrm{~N}\right]$ HSQC NMR spectra, several indistinguishable, non-discrete conformers were observed on completion of the reaction (bifunctional binding) for both $\mathbf{1}$ and $\mathbf{1}^{\prime}$. This is in contrast to $1,0,1 / t, t, t$ where two clear conformers were observed.

To our knowledge this is the first observation of a polyamine-DNA interaction using $2 \mathrm{D}\left[{ }^{1} \mathrm{H}\right.$, $\left.{ }^{15} \mathrm{~N}\right]$ HSQC NMR spectroscopy. Direct ${ }^{15} \mathrm{~N}$ observation has allowed the sites and sequence of amine protonation to be determined. ${ }^{38}$ In the presence of tRNA, the longitudinal relaxation times of the ${ }^{15} \mathrm{~N}$ amines of spermidine and spermine were diminished. ${ }^{37}$ Spermine reacted more strongly than spermidine and, interestingly, the $-\mathrm{NH}_{2}-$ groups reacted stronger than terminal $-\mathrm{NH}_{3}-$, suggesting that both electrostatic and $\mathrm{H}$-bonding were important factors in the interaction. ${ }^{13} \mathrm{C}$ NMR relaxation and heteronuclear NOE experiments have also been used to compare the dynamics of binding of spermidine to duplex and quadruplex DNA. ${ }^{40}$ The binding of spermine to the self-complementary DNA sequence d(CGCGAATTCGCG) $)_{2}$ showed that, although the 
polyamine has a binding constant of approximately $10^{6}$ at the low ionic strength employed for the experiments, the nature of the complex and the lifetime of the ligand on the DNA meant that the mobility of the spermine molecule was effectively independent of that of the polynucleotide. ${ }^{32}$ In contrast, ${ }^{1} \mathrm{H}$ and ${ }^{31} \mathrm{P}$ NMR studies showed decreased mobility of spermine in the Z-form of $\mathrm{d}(\mathrm{m} 5 \mathrm{CGm} 5 \mathrm{CGm} 5 \mathrm{CG})_{2}$ although no clear evidence of intermolecular spermine-DNA proton NOE contacts was observed. ${ }^{41}$ The ability to "anchor" the polyamine on the double helix through formation of the terminal Pt-N7 bonds is a novel approach to examine the polyamine linker flexibility and is extendable to spermine itself, where the distance between the central $-\mathrm{NH}_{2}-$ groups is sufficient to avoid the ${ }^{1} \mathrm{H}$ exchange between the two ${ }^{15} \mathrm{~N}$ atoms. ${ }^{33}$

The results reported here confirm the previous observations that the polyamine induces very small quantitative changes on the DNA/RNA spectrum. ${ }^{32,37}$ However, the observations of the extent - or delocalization - of the interaction could have implications for the understanding of conformational transitions on DNA facilitated by polyamines and polyvalent cations in general, especially the $\mathrm{B} \rightarrow \mathrm{Z}$ transition. ${ }^{42}$ The "pre-association" for the 6,6-linker (1) is centered on the minor groove $\left(A_{7}-A_{11}\right)$ whereas for the longer 6,2,6-linker $\left(\mathbf{1}^{\prime}\right)$ it is apparently delocalized over the whole sequence (see Figure 3). The rare minor groove placement has been observed in the Z-form of d(CGCGCG $)_{2}$ induced by spermine and structurally modified polyamines, ${ }^{43,44}$ although they are usually placed in the major groove of DNA. ${ }^{45-47}$ Crystallographic and computational studies on polyamine-DNA interactions have been interpreted from the point of view that the polyamines may interact with the minor groove by electrostatic scanning of the DNA surface before "settling" into the most stable complex in the major groove. ${ }^{29,47}$ The results for $\mathbf{1}$ and $\mathbf{1}^{\prime}$ are in agreement with this understanding. 
The existence of Z-DNA in vivo is now accepted but there is continued discussion on the mechanism and physiological role of this transition. ${ }^{30,48}$ The purine bases in Z-DNA adopt the syn conformation whereas the pyrimidines remain in the anti orientation due to steric constraints. The $\mathrm{B} \rightarrow \mathrm{Z}$ transition is a highly cooperative one and a number of theories have been proposed for the mechanism. ${ }^{49}$ Prominent amongst these is the concept of a nucleation step where a short Z-DNA sequence is formed between two B-Z junctions and propagation then occurs through flipping of the intervening base pairs. ${ }^{50}$ The delocalization observed for the DNA backbone is at least consistent with this zipper model ${ }^{51}$ showing as it does the presence of H-bonding and electrostatic interactions over a suitable 4 or $>4$ bp nucleation sequence. Two structural features of polynuclear platinum-DNA binding - (i) NMR and crystallographic evidence of the minor groove placement of the linker in non-covalent complexes with the Dickerson Drew Dodecamer ${ }^{52,53}$ and also in isolated covalently bound 1,4 interstrand cross-links ${ }^{14,20}$ and (ii) the induction of the syn conformation upon monofunctional Pt binding to G N7,,$^{14,20,54}$ suggests that the 1,4-crosslink described here, and previously, ${ }^{11,14,20}$ is "primed" to nucleate conformational transitions because of the simultaneous conformational changes from guanine platination and backbone polyamine-polynucleotide interactions. These features may be relevant to possible intermediate states in the $\mathrm{B} \rightarrow \mathrm{Z}$ transition. ${ }^{55,56}$ Indeed the range of distinct $\mathrm{Pt}-\mathrm{NH}_{2}$ environments found in the final conformers are indicative of interactions between the $\mathrm{NH}_{2}$ protons and the DNA as a result of changes in the DNA conformation. The slight but distinct changes in the central $-\mathrm{NH}_{2}-$ chemical shifts in going from pre-association, monofunctional to bifunctional binding also reflect different environments relative to the helix.

Polyamine analogs have been extensively examined for their antitumor activity. ${ }^{57-59}$ The major emphasis has been on disturbing the spermidine/spermine N1-acetyltransferase (SSAT) cycle 
rather than DNA conformational changes, as has been predominantly the case for platinum analog development. Polyamine catabolism is linked to antiproliferative activity and apoptosis. It is of considerable interest to note that both oxaliplatin and cisplatin stimulate the induction of polyamine catabolic enzymes such as SSAT by platinum drugs and biochemical responses and growth inhibition can be potentiated by co-treatment with polyamine analogs. ${ }^{60-62}$ Polyamines linked to DNA interacting moieties have also been used in attempts to target cytotoxics to cancer cells. ${ }^{63}$ Notably a chlorambucil-polyamine combination was significantly more cytotoxic than the simple alkylating agent reminiscent of the situation with $\mathbf{1}^{-64}$ In this sense the platinumpolyamines described here represent another class of these "chimeric" molecules with potential for dual biological activity - the polyamine conjugate contributes to the target reaction, without affecting the final outcome, in this case formation of $\{\mathrm{Pt}, \mathrm{Pt}\}$ interstrand crosslinks.

\section{CONCLUSIONS}

The polyamine-platinum compounds have been discussed as 2nd-generation polynuclear clinical candidates. Modification of leaving group using sterically hindering carboxylates has shown a 3-5fold increase in plasma stability over the parent dichloride, $\mathbf{1}^{\prime}$. A requirement for a 2 nd-generation analog is that chemical modification does not affect DNA-binding properties so that target interactions are similar to the parent drug (see for example cisplatin and carboplatin). The detailed kinetic analysis and comparison to $1,0,1 / t, t, t$ described here, combined with the global DNA binding profile reported confirms the utility of $\mathbf{1}^{\prime}$ and analogs for further development. Considering polyamine-DNA interactions, the novel approach of "anchoring" the polyamine on the Pt-G N7 bond allows observation of early events in its association with the double helix. 


\section{ASSOCIATED CONTENT}

Supporting Information. The ${ }^{1} \mathrm{H}$ assignments for duplex I, 2D $\left[{ }^{1} \mathrm{H},{ }^{15} \mathrm{~N}\right] \mathrm{HSQC}$ NMR spectra of $\mathbf{1}$ after addition to duplex $\mathbf{I}$ for $0.95 \mathrm{~h}$ showing peaks for three different pre-associated forms of $\mathbf{1}$ in the Pt- $\mathrm{NH}_{2}$ region, ${ }^{1} \mathrm{H}$ NMR spectra showing time dependent changes over the course of the reaction in the thymine- $\mathrm{CH}_{3}$ and imino regions of duplex $\mathbf{I}$ and the alkyl $\mathrm{CH}_{2}$ region of $\mathbf{1}$ and $\mathbf{1}^{\prime}$, and SCIENTIST models used to determine the rate constants given in Table 3. This material is available free of charge online at http://pubs.acs.org.

\section{AUTHOR INFORMATION}

\section{Corresponding Authors}

s.berners-price@griffith.edu.au,npfarrell@vcu.edu.

\section{ACKNOWLEDGEMENTS}

The authors thank the University of Western Australia for a University Postgraduate Award (RAR). This work was supported by the Australian Research Council (Discovery Grants to SBP and NF (DP0662817 and DP1095383)).

\section{REFERENCES}

(1) Hurley, L. H. Nat. Rev. Cancer 2002, 2, 188-200.

(2) Boer, D. R.; Canals, A.; Coll, M. Dalton Trans. 2009, 399-414.

(3) Farrer, N. J.; Salassa, L.; Sadler, P. J. Dalton Trans. 2009, 10690-10701.

(4) Choi, J.; Majima, T. Chem. Soc. Rev. 2011, 40, 5893-5909.

(5) Stulz, E.; Clever, G.; Shionoya, M.; Mao, C. Chem. Soc. Rev. 2011, 40, 5633-5635.

(6) Kelland, L. Nat. Rev. Cancer 2007, 7, 573-584. 
(7) Wang, D.; Lippard, S. J. Nat. Rev. Drug Discov. 2005, 4, 307-320.

(8) Farrell, N. Metal Ions in Biol. Sys., 2004, 41, 252-296.

(9) Mangrum, J. B.; Farrell, N. P. Chem. Commun. 2010, 6640-6650.

(10) Cox, J. W.; Berners-Price, S. J.; Davies, M. S.; Qu, Y.; Farrell, N. J. Am. Chem. Soc. 2001, $123,1316-1326$.

(11) Hegmans, A.; Berners-Price, S. J.; Davies, M. S.; Thomas, D. S.; Humphreys, A. S.; Farrell, N. J. Am. Chem. Soc. 2004, 126, 2166-2180.

(12) Kasparkova, J.; Zehnulova, J.; Farrell, N.; Brabec, V. J. Biol. Chem. 2002, 277, 4807648086.

(13) Ruhayel, R. A.; Moniodis, J. J.; Yang, X.; Kasparkova, J.; Brabec, V.; Berners-Price, S. J.; Farrell, N. P. Chem. Eur. J. 2009, 15, 9365 - 9374.

(14) Qu, Y.; Scarsdale, N. J.; Tran, M.-C.; Farrell, N. P. J. Biol. Inorg. Chem. 2003, 8, 19-28.

(15) Takahara, P. M.; Rosenzweig, A. C.; Frederick, C. A.; Lippard, S. J. Nature 1995, 377, 649-652.

(16) Gelasco, A.; Lippard, S. J. Biochemistry 1998, 37, 9230-9239.

(17) Ohndorf, U.-M.; Rould, M. A.; He, Q.; Pabo, C. O.; Lippard, S. J. Nature 1999, 399, 708712.

(18) Ohndorf, U. M.; Whitehead, J. P.; Raju, N. L.; Lippard, S. J. Biochemistry 1997, 36, 14807-14815.

(19) Qu, Y.; Moniodis, J. J.; Harris, A.; Yang, X.; Hegmans, A.; Povirk, L.; Berners-Price, S. J.; Farrell, N. P. In Polyamine Drug Discovery; Woster, P. M., Casero, R., Eds.; Royal Society of Chemistry: Cambridge, 2011, pp. 191-204.

(20) Qu, Y.; Scarsdale, N. J.; Tran, M.-C.; Farrell, N. J. Inorg. Biochem. 2004, 98, 1585-1590. 
(21) Rauter, H.; Di Domenico, R.; Menta, E.; Oliva, A.; Qu, Y.; Farrell, N. Inorg. Chem. 1997, $36,3919-3927$.

(22) McGregor, T. D.; Hegmans, A.; Kasparkova, J.; Neplechova, K.; Novakova, O.; Penazova, H.; Vrana, O.; Brabec, V.; Farrell, N. J. Biol. Inorg. Chem. 2002, 7, 397-404.

(23) Montero, E. I.; Benedetti, B. T.; Mangrum, J. B.; Oehlsen, M. J.; Qu, Y.; Farrell, N. P. Dalton Trans. 2007, 43, 4938-4942.

(24) Billecke, C.; Finniss, S.; Tahash, L.; Miller, C.; Mikkelsen, T.; Farrell, N. P.; Bogler, O. Neuro-Oncology 2006, 8, 215-226.

(25) Gatti, L.; Perego, P.; Leone, R.; Apostoli, P.; Carenini, N.; Corna, E.; Allievi, C.; Bastrup, U.; De Munari, S.; Di Giovine, S.; Nicoli, P.; Grugni, M.; Natangelo, M.; Pardi, G.; Pezzoni, G.; Singer, J. W.; Zunino, F. Mol. Pharmaceutics 2010, 7, 207-216.

(26) Mitchell, C.; Kabolizadeh, P.; Ryan, J.; Roberts, J. D.; Yacoub, A.; Curiel, D. T.; Fisher, P. B.; Hagan, M. P.; Farrell, N. P.; Grant, S.; Dent, P. Mol. Pharmacol. 2007, 72, 704-714.

(27) Summa, S.; Maigut, J.; Puchta, R.; van Eldik, R. Inorg. Chem. 2007, 46, 2094-2104.

(28) Zerzankova, L.; Suchankova, T.; Vrana, O.; Farrell, N. P.; Brabec, V.; Kasparkova, J.

Biochem. Pharmacol. 2010, 79, 112-121.

(29) Strekowski, L.; Mokrosz, M.; Mokrosz, J. L.; Strekowska, A.; Allison, S. A.; Wilson, W .

D. Anti-Cancer Drug Des. 1988, 3, 79-89.

(30) Rich, A. Nat. Struct. Biol. 2003, 10, 247-249.

(31) Berners-Price, S. J.; Ronconi, L.; Sadler, P. J. Prog. Nucl. Magn. Reson. Spectrosc. 2006, 49, 65-98.

(32) Geierstanger, B. H.; Wemmer, D. E. Annu. Rev. Biophys. Biomol. Struct. 1995, 24, 463-93. 
(33) Ruhayel, R. A.; Zgani, I.; Berners-Price, S. J.; Farrell, N. P. Dalton Trans. 2012, 4147 4154.

(34) Piotto, M.; Saudek, V.; Sklenar, V. J. Biomol. NMR 1992, 2, 661-665.

(35) McCoy, M. A.; Mueller, L. J. Magn. Reson., Ser. A 1993, 101, 122-130.

(36) Ruhayel, R. A.; Corry, B.; Braun, C.; Thomas, D. S.; Berners-Price, S. J.; Farrell, N. P. Inorg. Chem. 2010, 49, 10815-10819.

(37) Frydman, L.; Rossomando, P. C.; Frydman, V.; Fernandez, C. O.; Frydman, B.; Samejima, K. Proc. Natl. Acad. Sci. U. S. A. 1992, 89, 9186-9190.

(38) Takeda, Y.; Samejima, K.; Nagano, K.; Watanabe, M.; Sugeta, H.; Kyogoku, Y. Eur. J. Biochem. 1983, 130, 383-389.

(39) Fernandez, C. O.; Hoyer, W.; Zweckstetter, M.; Jares-Erijman, E. A.; Subramaniam, V.; Griesinger, C.; Jovin, T. M. EMBO J. 2004, 23, 2039-2046.

(40) Keniry, M. A. FEBS Lett. 2003, 542 153-158.

(41) Banville, D.; Feuerstein, B. G.; Shafer, R. H. J. Mol. Biol. 1991, 219, 585-590.

(42) Hou, M.-H.; Lin, S.-B.; Yuann, J.-M. P.; Lin, W.-C.; Wang, A. H.-J.; Kan, L.-s. Nucleic Acids Res. 2001, 29, 5121-5128.

(43) Ohishi, H.; Odoko, M.; Grzeskowiak, K.; Hiyama, Y.; Tsukamoto, K.; Maezaki, N.; Ishida, T.; Tanaka, T.; Okabe, N.; Fukuyama, K.; Zhou, D.-Y.; Nakatani, K. Biochem. Biophys. Res. Comm. 2008 366, 275-280.

(44) Ohishi, H.; Tozuka, Y.; Zhou, D.-Y.; Ishida, T.; Nakatani, K. Biochem. Biophys. Res. Comm. 2007, 358 24-28.

(45) Gessner, R. V.; Frederick, C. A.; Quigley, G. J.; Rich, A.; Wang, A. H.-J. J. Biol. Chem. 1989, 264, 7921-7935. 
(46) Jain, S.; Zon, G.; Sundaralingam, M. Biochemistry 1989, 28, 2360-2364.

(47) Strekowski, L.; Harden, D. B.; Wydra, R. L.; Stewart, K. D.; Wilson, W. D. J. Mol. Recognit. 1989, 2, 158-166.

(48) Rich, A.; Zhang, S. Nat. Rev. Genet. 2003, 4, 566-572.

(49) Kastenholz, M. A.; Schwartz, T. U.; Hünenberger, P. H. Biophys. J. 2006, 91, 2976-2990.

(50) Ha, S. C.; Lowenhaupt, K.; Rich, A.; Kim, Y.-G.; Kim, K. K. Nature 2005, 437, 1183 1186.

(51) Ho, P. S. Proc. Natl. Acad. Sci. U. S. A. 1994, 91, 9549-9553.

(52) Komeda, S.; Moulaei, T.; Chikuma, M.; Odani, A.; Kipping, R.; Farrell, N. P.; Williams, L. D. Nuc. Acids Res. 2011, 39, 325-336.

(53) Komeda, S.; Moulaei, T.; Woods, K. K.; Chikuma, M.; Farrell, N. P.; Williams, L. D. J. Amer. Chem. Soc. 2006, 128, 16092-16103.

(54) Parkinson, G. N.; Arvanitis, G. M.; Lessinger, L.; Ginell, S. L.; Jones, R.; Gaffney, B.; Berman, H. M. Biochemistry 1995, 34, 15487-15495.

(55) Bothe, J. R.; Lowenhaupt, K.; Al-Hashimi, H. M. J. Amer. Chem. Soc. 2011, 133, 20162018.

(56) Grzeskowiak, K.; Ohishi, H.; Ivanov, V. Nuc. Acids Symp Ser. 2005, 49, 249-250.

(57) Casero Jr., R. A.; Woster, P. M. J. Med. Chem. 2009, 52, 4551-4573.

(58) Senanayake, M. D. T.; Amunugama, H.; Boncher, T. D.; Casero, R. A., Jr.; Woster, P. M. Essays Biochem. 2009, 46, 77-94.

(59) Gerner, E. W.; Meyskens, F. L., Jr. Nat. Rev. Cancer 2004, 4, 781-792.

(60) Bassett, E.; King, N. M.; Bryant, M. F.; Hector, S.; Pendyala, L.; Chaney, S. G.; CordeiroStone, M. Cancer Res. 2004, 64, 6469-6475. 
(61) Hector, S.; Porter, C. W.; Kramer, D. L.; Clark, K.; Prey, J.; Kisiel, N.; Diegelman, P.; Chen, Y.; Pendyala, L. Mol. Cancer Ther. 2004, 3, 813-822.

(62) Hector, S.; Tummala, R.; Kisiel, N. D.; Diegelman, P.; Vujcic, S.; Clark, K.; Fakih, M.; Kramer, D. L.; Porter, C. W.; Pendyala, L. Cancer Chemother. Pharmacol. 2008, 62, 517-527.

(63) Cullis, P. M.; Green, R. E.; Malone, M. E.; Merson-Davies, L.; Weaver, R. Biochem. Soc. Trans. 1994, 22, 402S.

(64) Holley, J. L.; Mather, A.; Wheelhouse, R. T.; Cullis, P. M.; Hartley, J. A.; Bingham, J. P.; Cohen, G. M. Cancer Res. 1992, 52, 4190-4195.

(65) Lemaire, D.; Fouchte, M. H.; Kozelka, J. J. Inorg. Biochem. 1994, 53, 261-271.

(66) Davies, M. S.; Thomas, D. S.; Hegmans, A.; Berners-Price, S. J.; Farrell, N. Inorg. Chem. 2002, 41, 1101-1109. 

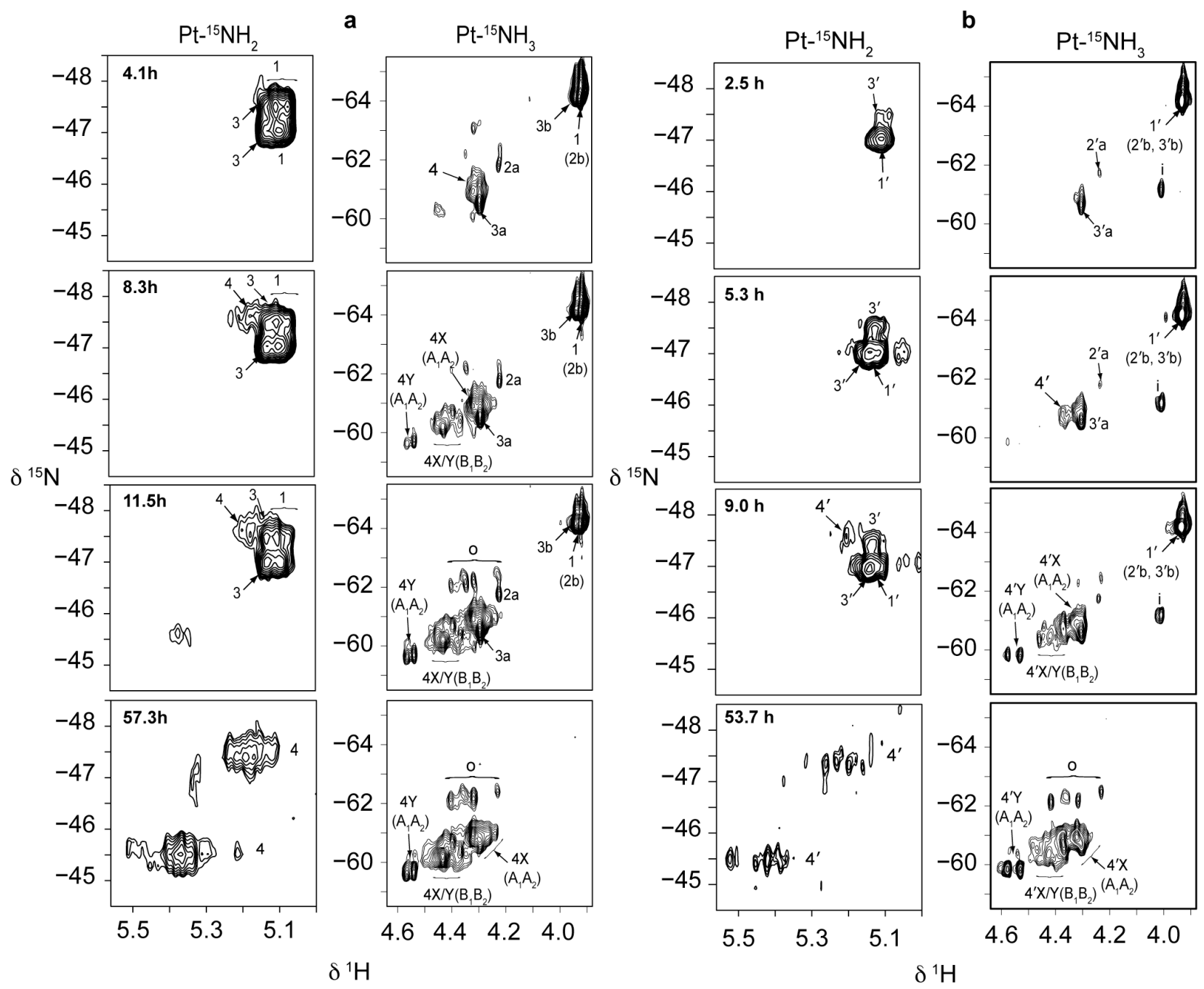

Figure 1. 2D $\left[{ }^{1} \mathrm{H},{ }^{15} \mathrm{~N}\right]$ HSQC NMR $(600 \mathrm{MHz})$ spectra recorded at $298 \mathrm{~K}$ of $\mathbf{1}$ (a) and $\mathbf{1}^{\prime}$ (b) after their addition to duplex $\mathbf{I}$ for the times shown. Peaks have been assigned to the $\mathrm{Pt}^{15} \mathrm{NH}_{3}$ and Pt- ${ }^{15} \mathrm{NH}_{2}$ structures shown in Scheme 1. Peaks labeled 'o' are assigned to other products (possibly adenine bound $^{65}$ - see also Figure 2) and are similar to those observed in the reactions of $\mathbf{I}$ with $1,1 / t, t^{10}$ and $1,0,1 / t, t, t .{ }^{11}$ The peak labeled ' $\mathrm{i}$ ' is assigned to a minor polymeric ${ }^{15} \mathrm{~N}$-labeled impurity with dangling amines in the sample of $\mathbf{1}^{\prime}$ (see reference ${ }^{33}$ ). 
a

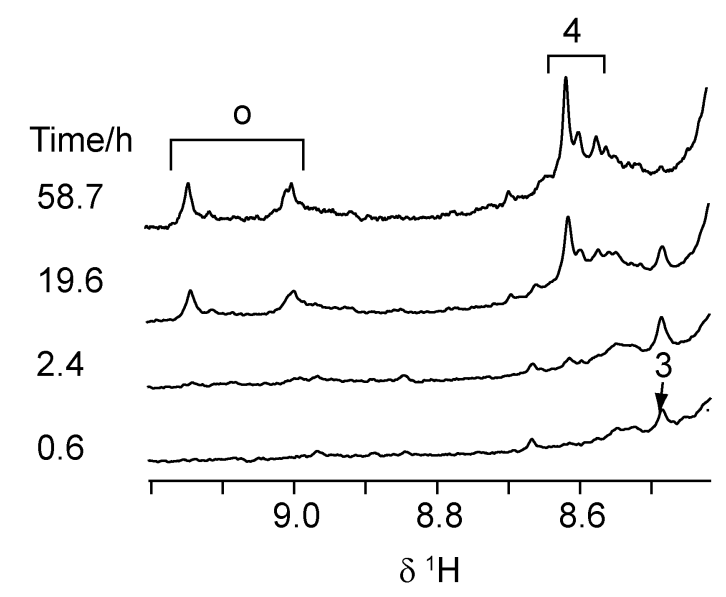

b

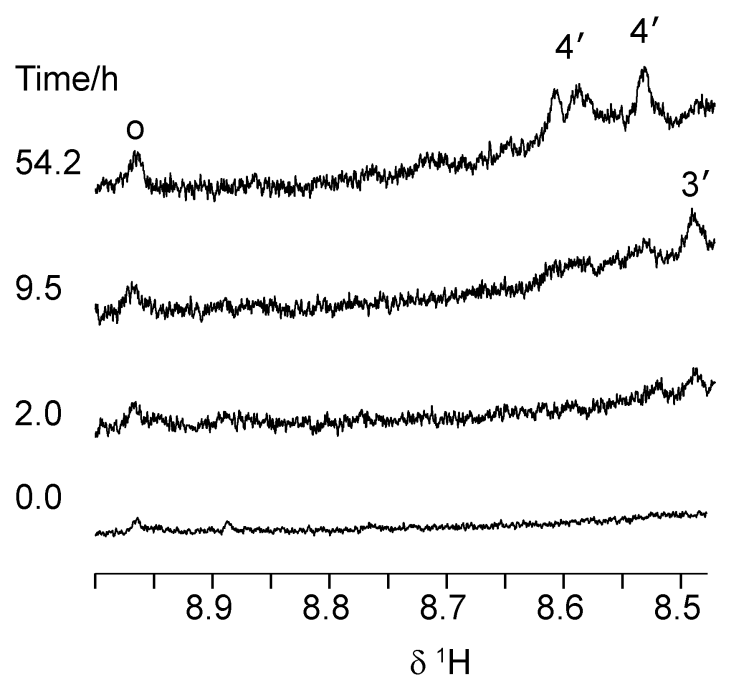

Figure 2. The aromatic regions of the ${ }^{1} \mathrm{H}$ NMR spectra $(600 \mathrm{MHz})$ of duplex $\mathbf{I}$ after the addition of 1 (a) and $\mathbf{1}^{\prime}$ (b) for the times shown. Assignments have been made for the monofunctional species,

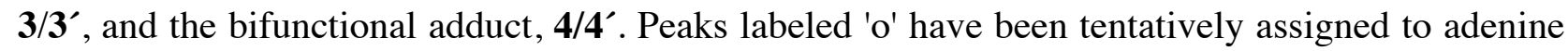
bound adducts based on previous assignments. ${ }^{65}$ 


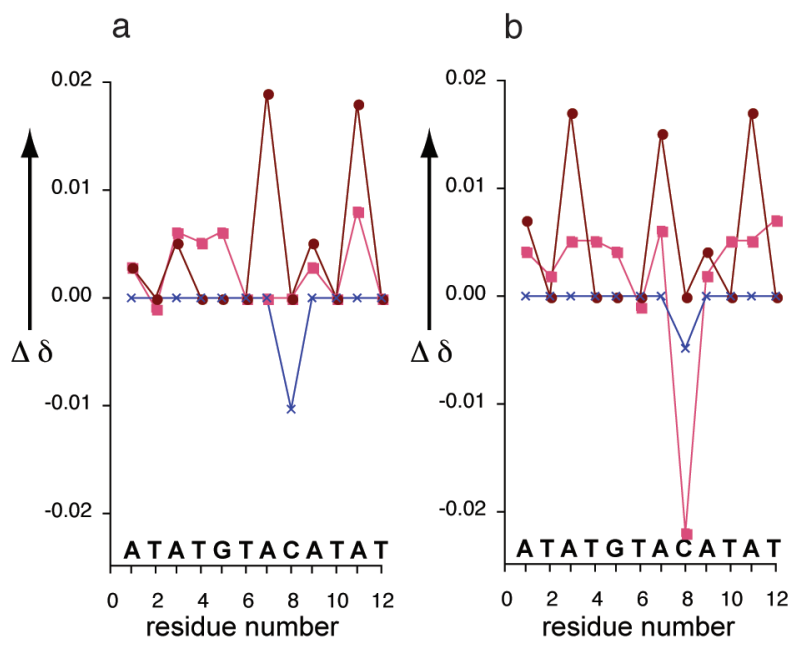

Figure 3. ${ }^{1} \mathrm{H}$ chemical shift changes $(\Delta \delta=\delta($ duplex I: PPC) $-\delta($ duplex I) $)$ seen after the addition of 1 (a) or 1' (b) to duplex I. Key: circles (brown) H2 protons; squares (red) aromatic H8/H6 protons; $\times$ (blue) H41 protons. 


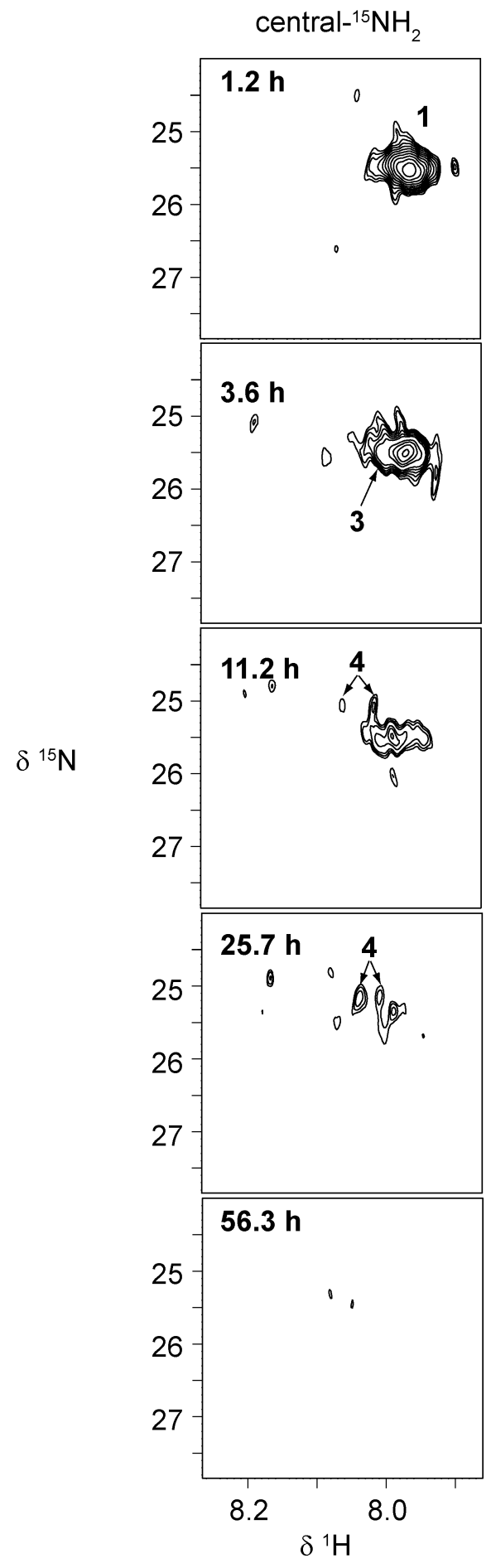

Figure 4. 2D $\left[{ }^{1} \mathrm{H},{ }^{15} \mathrm{~N}\right]$ HSQC NMR $(600 \mathrm{MHz})$ spectra of the central $-{ }^{15} \mathrm{NH}_{2}-$ region of $\mathbf{1}$ after its addition to duplex I for the times shown. Peaks have been assigned to the structures shown in Scheme 1. 
a
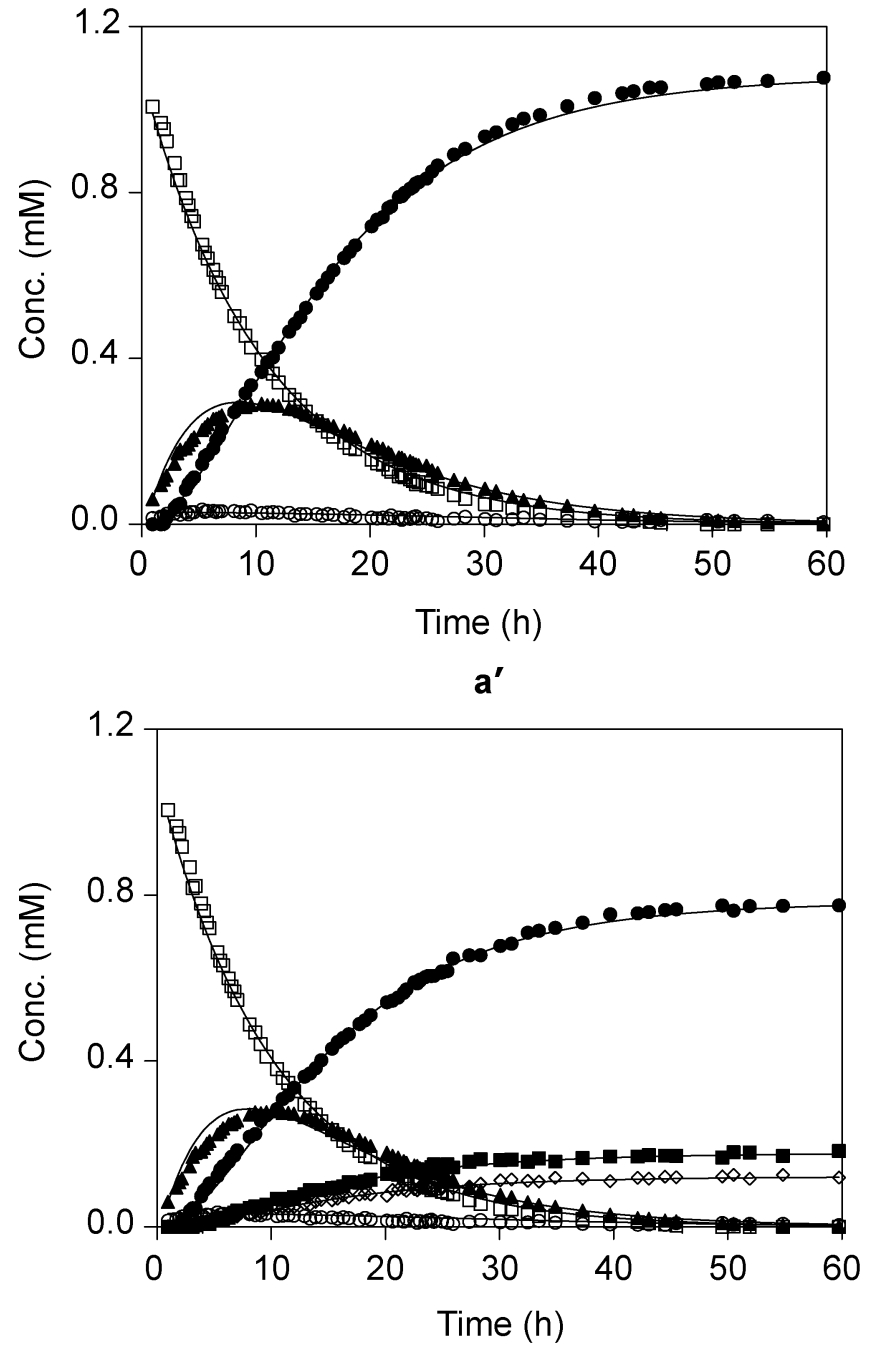

b

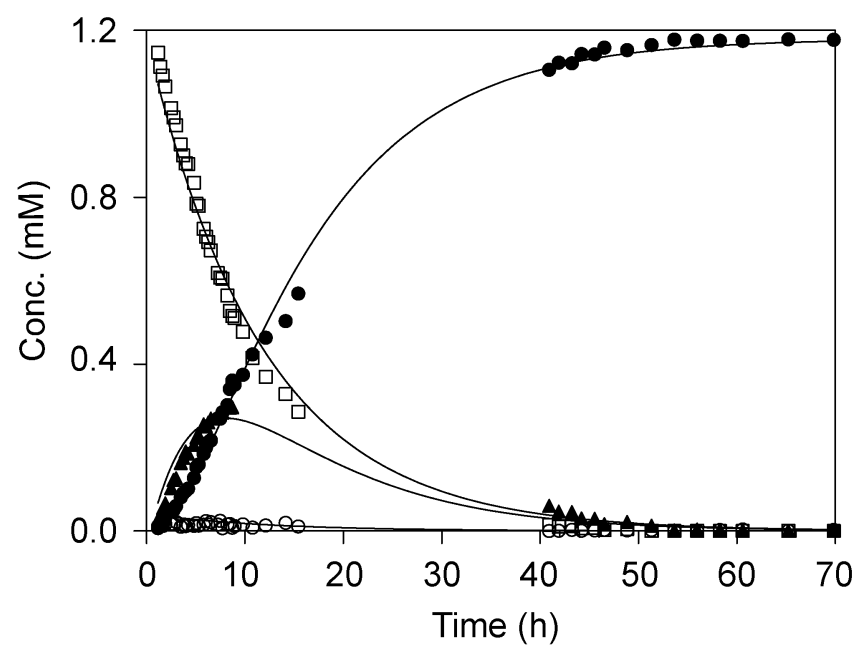

$b^{\prime}$

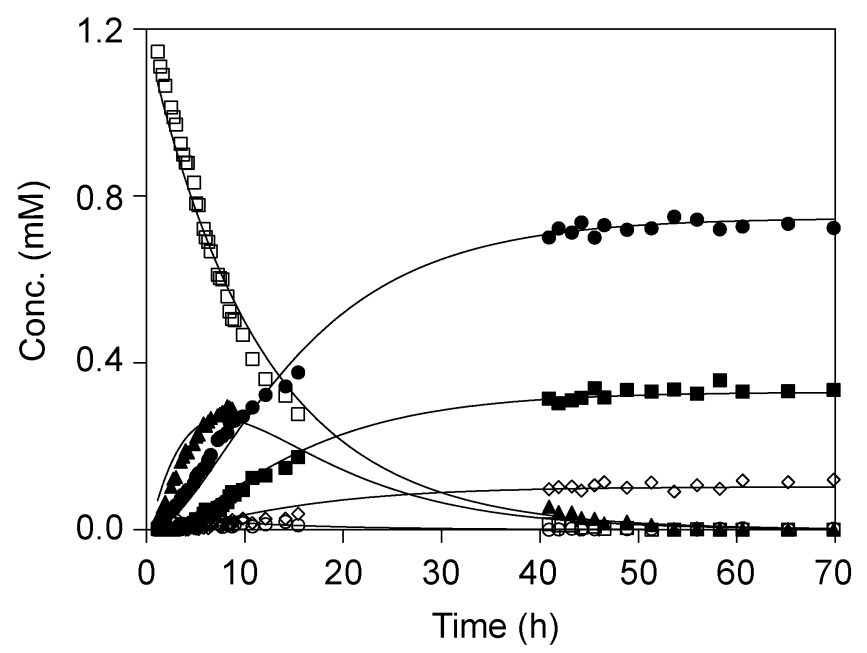

Figure 5. Plots of relative concentrations of species observed during reaction of $\mathbf{1}\left(\mathrm{a} / \mathrm{a}^{\prime}\right)$ or $\mathbf{1}^{\prime}$ (b/b') with duplex I, based on intensities of the cross-peaks in the $\mathrm{Pt}-{ }^{15} \mathrm{NH}_{3}$ region of the $2 \mathrm{D}\left[{ }^{1} \mathrm{H}\right.$, $\left.{ }^{15} \mathrm{~N}\right]$ HSQC spectra. The curves are computer best fits for the rate constants shown in Table 3, which were fit to either Model I (a/b) or Model II ( $\left.a^{\prime}, b^{\prime}\right)$ (Scheme 1). Labels: dichloro species $\left(\mathbf{1} / \mathbf{1}^{\prime}\right)$ open squares; aqua species $\left(\mathbf{2} / \mathbf{2}^{\prime}\right)$ open circles; monofunctional species $\left(\mathbf{3} / \mathbf{3}^{\prime}\right)$ filled triangles; bifunctional adduct $\left(\mathbf{4}^{\prime} \mathbf{4}^{\prime}\right)$ filled circles; other products open diamonds. ( $a^{\prime}$ and $b^{\prime}$ ) show the formation of the minor ( $\mathbf{4} \mathbf{Y} / \mathbf{4}^{\prime} \mathbf{Y}$, filled squares) and other conformers $\left(\mathbf{4 X} / \mathbf{4}^{\prime} \mathbf{X}\right.$, filled circles) of the 1,4-interstrand cross-link, which are shown as combined products in (a and b). 

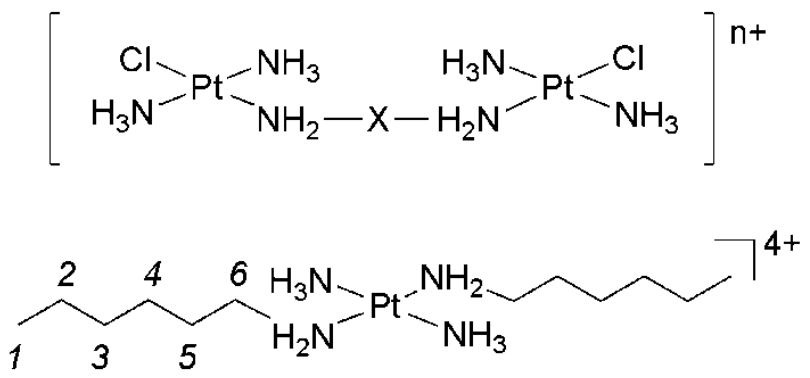

$1,0,1 / t, t, t$ or BBR3464

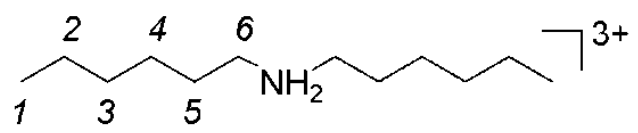

$1,1 / t, t-6,6$ or BBR3007 (1)

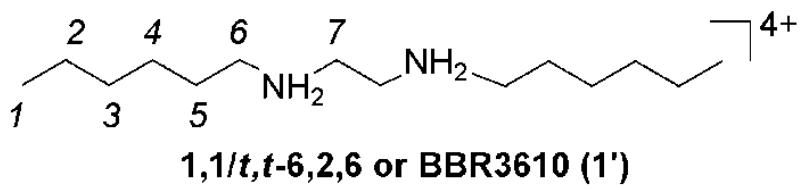

Chart 1. General structures di- and trinuclear complexes, 1,0,1/t,t,t, 1,1/t,t-6,6 (1) and 1,1/t,t-6,2,6 $\left(1^{\prime}\right)$. 

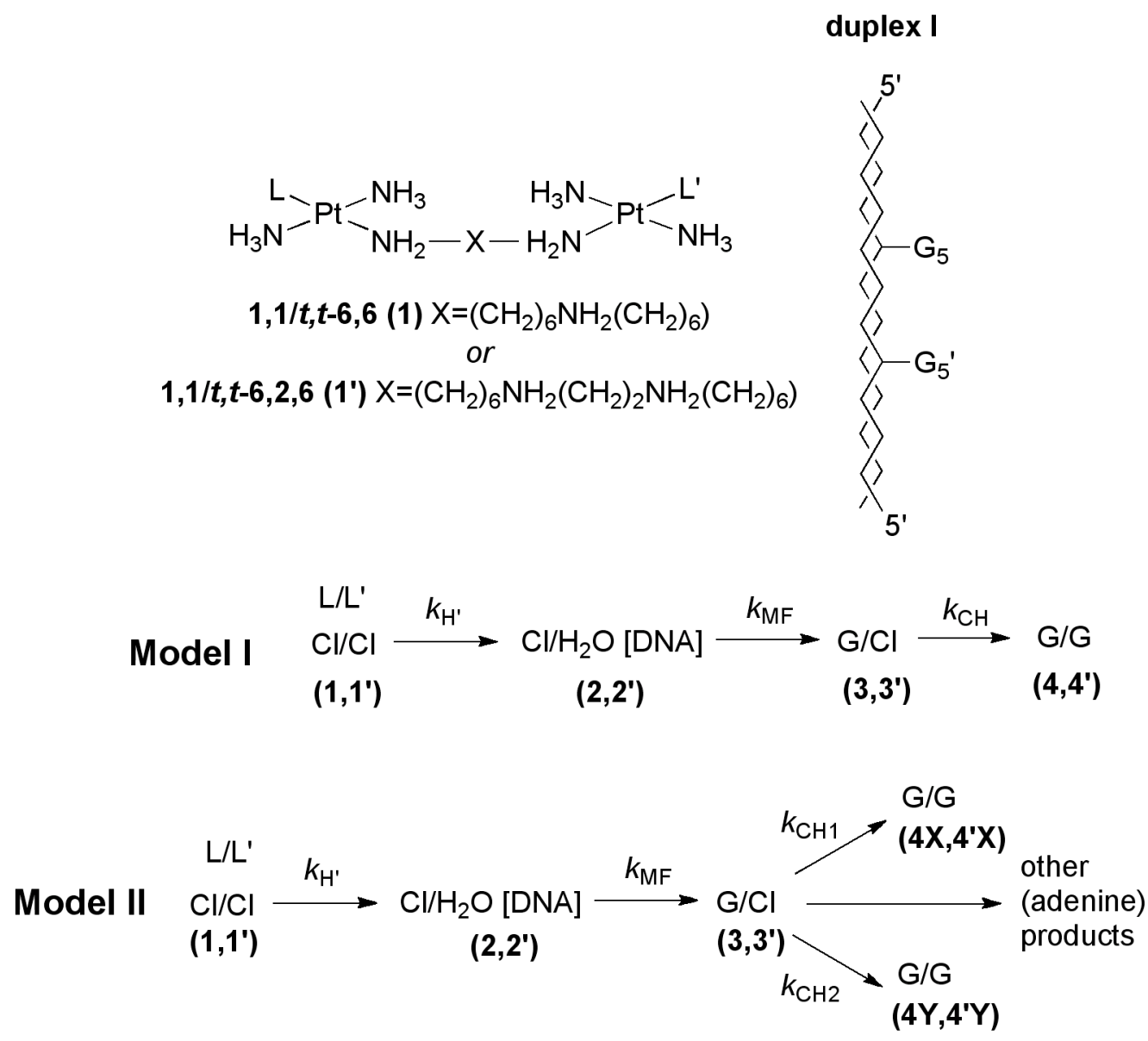

Scheme 1. Interstrand Cross-linking of $\mathbf{1}$ and $\mathbf{1}^{\prime}$ with Duplex $\mathbf{I}$, according to the two Kinetic Models I and II. 
Table 1. ${ }^{1} \mathrm{H} /{ }^{15} \mathrm{~N}$ Chemical Shifts for the $\mathrm{Pt}-{ }^{15} \mathrm{NH}_{3}$ and $\mathrm{Pt}-{ }^{15} \mathrm{NH}_{2}$ Groups of $\mathbf{1}$ and $\mathbf{1}^{\prime}$ and the Intermediate Species Observed during their Reactions with Duplex I (at 298K, pH 5.4). ${ }^{a}$ Data for $1,0,1 / t, t, t$ and 1,1/t,t are shown for comparison.

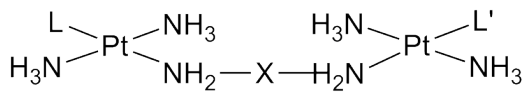

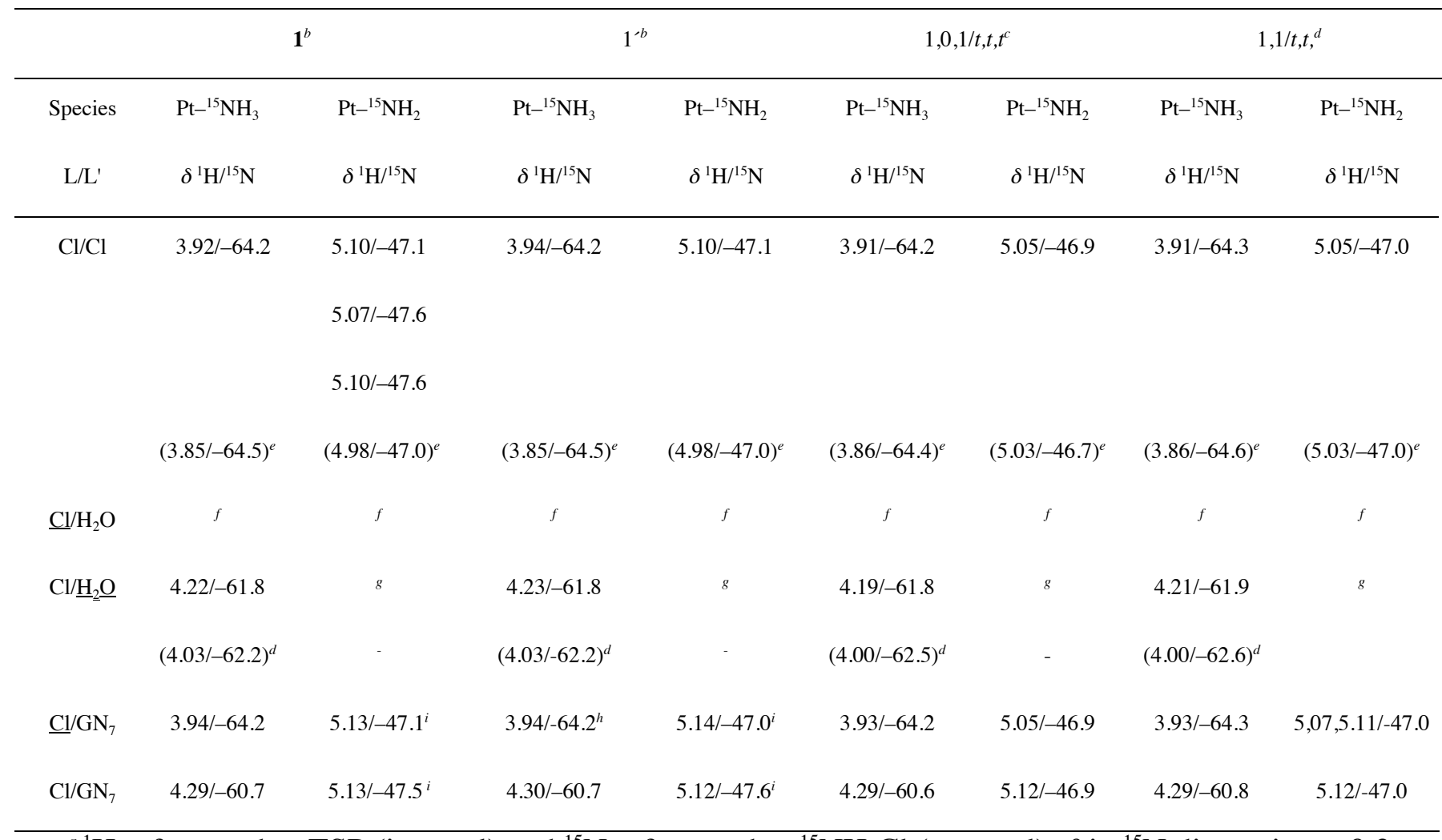

${ }^{a}{ }^{1} \mathrm{H}$ referenced to TSP (internal) and ${ }^{15} \mathrm{~N}$ referenced to ${ }^{15} \mathrm{NH}_{4} \mathrm{Cl}$ (external). $\delta$ in ${ }^{15} \mathrm{~N}$ dimension \pm 0.2 ppm. ${ }^{b}$ This work. ${ }^{c}$ From reference ${ }^{11} .{ }^{d}$ From reference ${ }^{10} .{ }^{e}$ The ${ }^{1} \mathrm{H} /{ }^{15} \mathrm{~N}$ chemical shifts in the absence of DNA at $\mathrm{pH} 5.4 .{ }^{f}$ Assumed to be concealed underneath the cross-peak corresponding to the $\mathrm{Cl} / \mathrm{Cl}$ species. ${ }^{g}$ Assumed to lie too close to the ${ }^{1} \mathrm{H}_{2} \mathrm{O}$ peak to be detected. ${ }^{h}$ Partially obscured by the dichloro crosspeak (see text). ${ }^{i}$ Assignments for $\underline{\mathrm{Cl}} / \mathrm{GN}_{7}$ and $\mathrm{Cl} / \underline{\mathrm{GN}}_{7}$ could be reversed. 
Table 2. ${ }^{1} \mathrm{H} /{ }^{15} \mathrm{~N}$ Chemical Shifts for the Pt $-{ }^{15} \mathrm{NH}_{3}$ Groups of the Conformers of the Final Products (4/4') formed in the Reactions of $\mathbf{1}$ and $\mathbf{1}^{\prime}$ and $1,0,1 / t, t, t$ with Duplex I (at $298 \mathrm{~K}, \mathrm{pH}$ 5.4). ${ }^{a}$

\begin{tabular}{|c|c|c|c|c|c|c|}
\hline \multirow{3}{*}{ Species $^{d}$} & \multicolumn{2}{|c|}{$\mathbf{1}^{b}$} & \multicolumn{2}{|c|}{$\mathbf{1}^{\prime b}$} & \multicolumn{2}{|c|}{$1,0,1 / t, t, t^{c}$} \\
\hline & $\mathrm{A}_{1} / \mathrm{A}_{2}$ & $\mathrm{~B}_{1} / \mathrm{B}_{2}$ & $\mathrm{~A}_{1} / \mathrm{A}_{2}$ & $\mathrm{~B}_{1} / \mathrm{B}_{2}$ & $\mathrm{~A}_{1} / \mathrm{A}_{2}$ & $\mathrm{~B}_{1} / \mathrm{B}_{2}$ \\
\hline & $\delta{ }^{1} \mathrm{H} /{ }^{15} \mathrm{~N}$ & $\delta{ }^{1} \mathrm{H} /{ }^{15} \mathrm{~N}$ & $\delta{ }^{1} \mathrm{H} /{ }^{15} \mathrm{~N}$ & $\delta{ }^{1} \mathrm{H} /{ }^{15} \mathrm{~N}$ & $\delta{ }^{1} \mathrm{H} /{ }^{15} \mathrm{~N}$ & $\delta{ }^{1} \mathrm{H} /{ }^{15} \mathrm{~N}$ \\
\hline \multirow[t]{2}{*}{ conformer(s) $\mathbf{X}$} & $4.32 /-61.0^{e}$ & $4.43 /-60.4^{e}$ & $4.30 /-60.8$ & $4.37 /-60.8^{e}$ & $4.30 /-60.9$ & $4.37 /-60.6$ \\
\hline & & & & & & $4.35 /-60.9$ \\
\hline \multirow[t]{2}{*}{ conformer $\mathbf{Y}$} & $4.57 /-59.7$ & $4.43 /-60.4^{e}$ & $4.58 /-59.9$ & $4.37 /-60.8^{e}$ & $4.57 /-59.7$ & $4.37 /-60.6$ \\
\hline & $4.54 /-59.7$ & & $4.53 /-59.8$ & & $4.51 /-59.9$ & $4.35 /-60.9$ \\
\hline
\end{tabular}

${ }^{a} \mathrm{H}$ referenced to TSP (internal) and ${ }^{15} \mathrm{~N}$ referenced to ${ }^{15} \mathrm{NH}_{4} \mathrm{Cl}$ (external). ${ }^{b}$ This work. ${ }^{c}$ From reference. ${ }^{11}{ }^{d}$ Two discrete conformers $(\mathbf{X}$ and $\mathbf{Y})$ are observed for $1,0,1 / t, t, t$ but not in the case of $\mathbf{1}$ or 1' (see text). ${ }^{e}$ Broad cluster of overlapped peaks. 
Table 3. Rate Constants for the Reactions of $\mathbf{1}$ and $\mathbf{1}^{\prime}$ with Duplex I (at $\left.298 \mathrm{~K}, \mathrm{pH} 5.4\right)^{a}$

\begin{tabular}{|c|c|c|c|c|c|c|}
\hline \multirow[b]{2}{*}{ Rate constant } & \multicolumn{2}{|c|}{1} & \multicolumn{2}{|c|}{$1^{\prime}$} & \multicolumn{2}{|c|}{$1,0,1 / t, t, t^{b}$} \\
\hline & Model I & Model II & Model I & Model II & Model I & Model II \\
\hline \multirow[t]{2}{*}{$k_{\mathrm{H}^{\prime}}\left(10^{-5} \mathrm{~s}^{-1}\right)^{c}$} & $2.61 \pm 0.01$ & $2.71 \pm 0.01$ & $2.33 \pm 0.03$ & $2.40 \pm 0.03$ & $3.94 \pm 0.03$ & $3.93 \pm 0.04$ \\
\hline & $(7.2 \pm 0.2)$ & & $(4.0 \pm 0.2)$ & & $(10.7 \pm 0.1)$ & \\
\hline$k_{\mathrm{MF}}\left(\mathrm{M}^{-1} \mathrm{~s}^{-1}\right)$ & $0.87 \pm 0.05$ & $0.89 \pm 0.06$ & $c$ & $c$ & $0.25 \pm 0.02$ & $0.24 \pm 0.02$ \\
\hline$k_{\mathrm{CH}}\left(10^{-5} \mathrm{~s}^{-1}\right)$ & $4.37 \pm 0.04$ & $3.41 \pm 0.03$ & $5.4 \pm 0.2$ & $3.6 \pm 0.1$ & $4.21 \pm 0.06$ & $3.00 \pm 0.05$ \\
\hline$k_{\mathrm{CH} 2}\left(10^{-5} \mathrm{~s}^{-1}\right)^{d}$ & & $0.74 \pm 0.01$ & & $1.59 \pm 0.06$ & & $1.21 \pm 0.03$ \\
\hline
\end{tabular}

${ }^{a}$ The rate constants are defined in Scheme 1 for models I and II. In the case of model II other species observed at the completion of the reaction were summed as "other products" and taken into account in the calculations but the rate constants obtained are meaningless and are not included here. ${ }^{b}$ From reference ${ }^{11} .{ }^{b}$ Data shown in parentheses are rate constants for the aquation step in the absence of DNA under identical ionic strength and $\mathrm{pH}$ (from references ${ }^{33,66}$ ). ${ }^{c}$ The rate constant for the monofunctional binding step could not be obtained due to the absence of data for the concentration of $\mathbf{3}^{\prime}$ between $15-40 \mathrm{~h}$ (see text and Figure 5). ${ }^{d}$ The reaction between $1,0,1 / t, t, t$ and duplex $\mathbf{I}$ affords two conformers of the 1,4 interstrand adduct, the rate constant $k_{\mathrm{CH} 2}$ relates to the formation of the less abundant conformer $(\mathrm{Y})$ and in that case $k_{\mathrm{CH}}$ relates to the formation of the other (major) conformer $(\mathrm{X}) .{ }^{11}$ For the reactions of $\mathbf{1}$ and $\mathbf{1}^{\prime} k_{\mathrm{CH} 2}$ similarly relates to the formation of the distinct minor conformer, but there also several other conformers, which are summed together to provide the rate constant $k_{\mathrm{CH}}$. 


\section{Graphical Abstract}

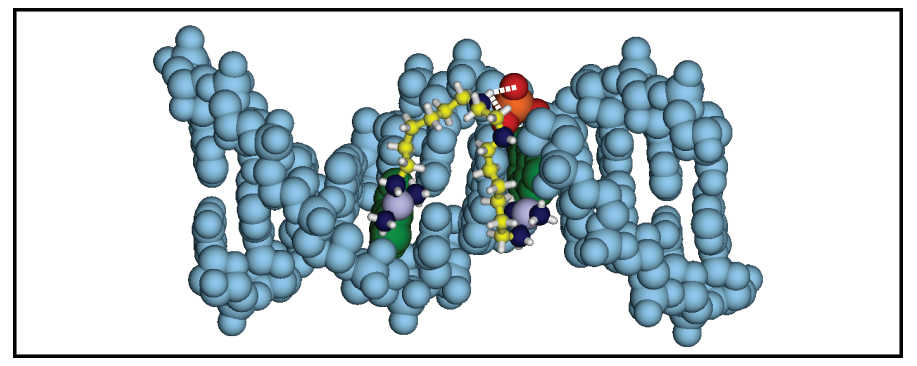

